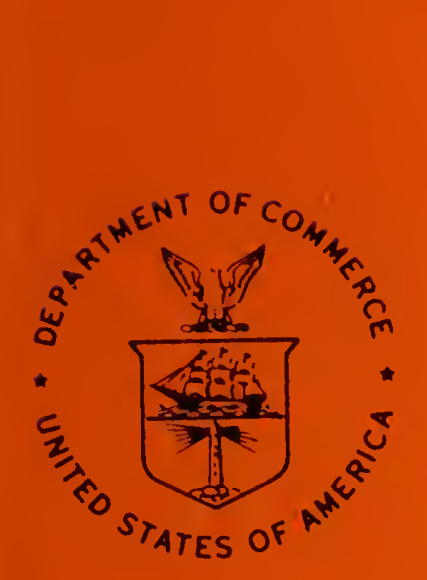

NOAA Technical Report NMFS Circular 412

\title{
Synopsis of Biological Data on the Red Porgy, Pagrus pagrus (Linnaeus)
}

May 1978

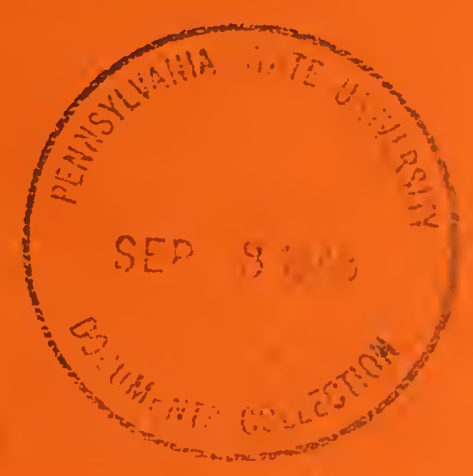

\section{FAO Fisheries Synopsis No. 116 \\ NMFS/S 116 \\ SAST-Red Porgy \\ $170(39) 49103$}

U.S. DEPARTMENT OF COMMERCE National Oceanic and Atmospheric Administration National Marine Fisheries Service 



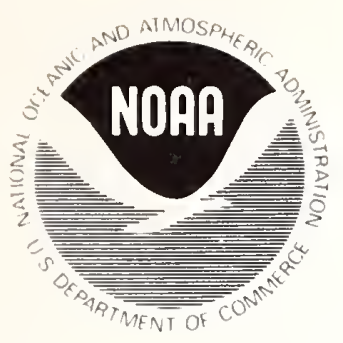

NOAA Technical Report NMFS Circular 412

Synopsis of Biological Data

on the Red Porgy,

Pagrus pagrus (Linnaeus)

Charles S. Manooch III and William W. Hassler

May 1978

FAO Fisheries Synopsis No. 116

U.S. DEPARTMENT OF COMMERCE

Juanita M. Kreps, Secretary

National Oceanic and Atmospheric Administration

Richard A. Frank, Administrator

National Marine Fisheries Service

For Sale by the Superintendent of Documents, U.S. Government Printing Office
Washington, D.C. 20402 Stock No. 003-017-00418-0 
The National Marine Fisheries Service (NMFS) does not approve, recommend or endorse any proprietary product or proprietary material mentioned in this publication. No reference shall be made to NMFS, or to this publication furnished by NMFS, in any advertising or sales promotion which would indicate or imply that NMFS approves, recommends or endorses any proprietary product or proprietary material mentioned herein, or which has as its purpose an intent to cause directly or indirectly the advertised product to be used or purchased because of this NMFS publication. 


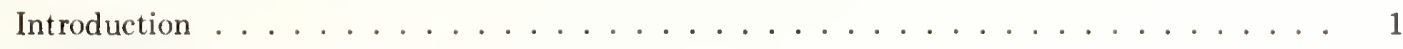

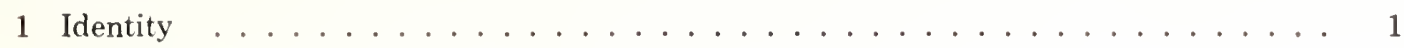

1.1 Nomenclature ... . . . . . . . . . . . . . . . . . . . . . . . 1

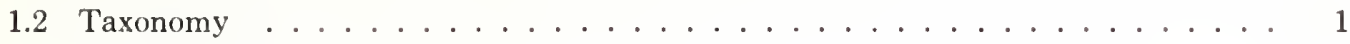

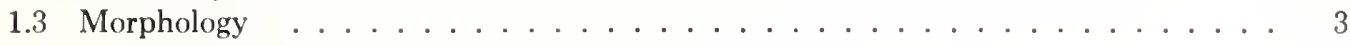

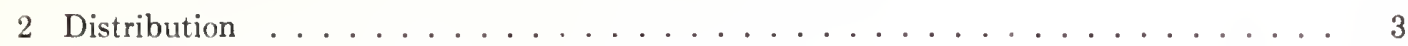

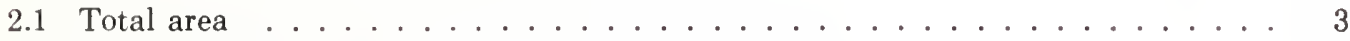

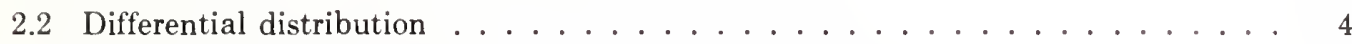

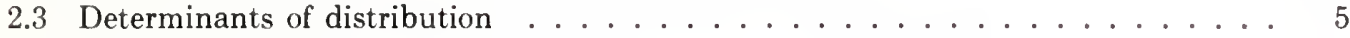

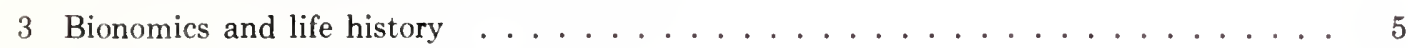

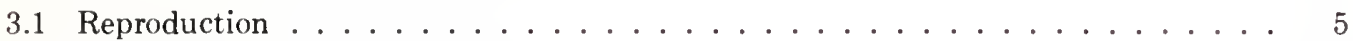

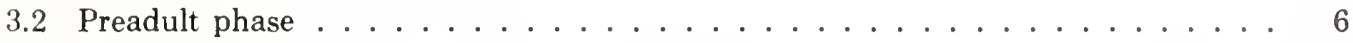

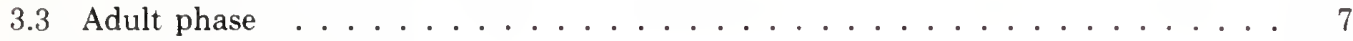

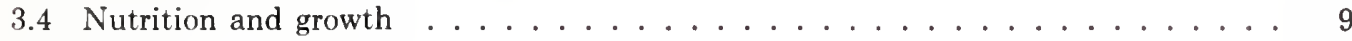

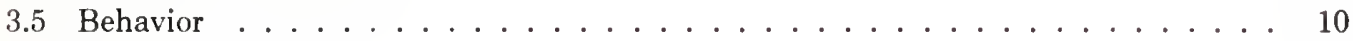

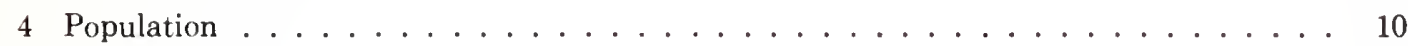

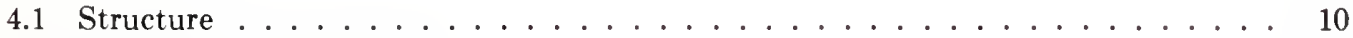

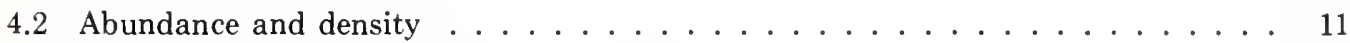

4.4 Mortality and morbidity . . . . . . . . . . . . . . . . . . 12

4.6 The population in the community and the ecosystem . . . . . . . . . . 13

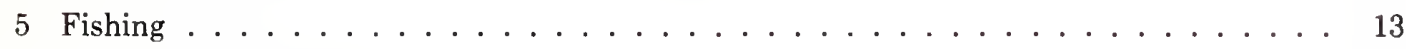

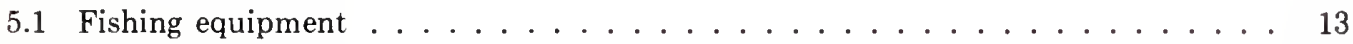

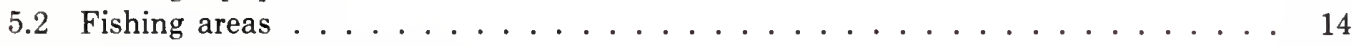

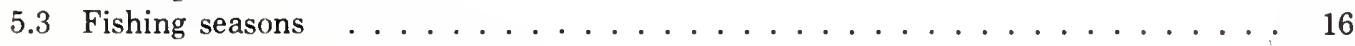

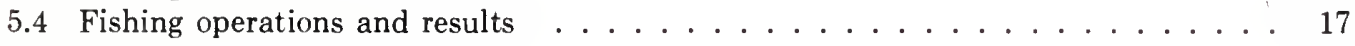

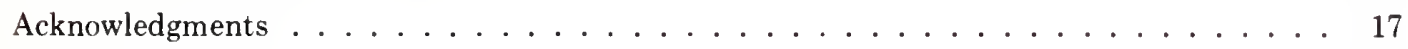

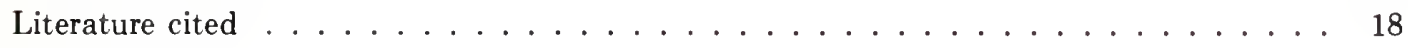





\title{
Synopsis of Biological Data on the Red Porgy, Pagrus pagrus (Linnaeus)
}

\author{
CHARLES S. MANOOCH III' ${ }^{1}$ and WILLIAM W. HASSLER ${ }^{2}$
}

\begin{abstract}
A synopsis of the biology of the red porgy, Pagrus pagrus, that includes taxonomy, morphology, distribution, aspects of the life history, behavior, and abundance. Also included are: discussions of commercial and recreational fishing methods and fishing grounds, and size, age, and sex composition of the recreational catch off North Carolina and South Carolina and commercial catch off Argentina.
\end{abstract}

\section{INTRODUCTION}

In recent years, the Fisheries Biology Branch of FAO has formed a "Synopsis Association" composed of various fishery agencies which have assisted in preparation of synopses on aquatic organisms of economic importance. Some of these synopses have been published in the U.S. Fish and Wildlife Service and the National Marine Fisheries Service Circular series following the format prescribed by Rosa (1965).

The major purpose of the synopses is to make existing information on various species of fishes and invertebrates easily accessible to scientists and the fishery constituencies according to a standard format. Gaps in knowledge will be exposed, thus delineating areas of research needs.

\section{IDENTITY}

\subsection{Nomenclature}

\subsection{Valid name}

Pagrus pagrus (Linnaeus 1758)

\subsection{Synonomy}

Sparus pagrus Linnaeus 1758:279, southern Europe.

Sparus orphus Linnaeus 1758:279, no locality.

Sparus argenteus Bloch and Schneider 1801:27, South America.

Pagrus orphus. Valenciennes 1837-1844:32, Canary Islands.

Pagrus pagrus. Valenciennes 1837-1844:32, Canary Islands.

Pagrus pagrus. Jordan and Gunn 1899:341, Canary Islands.

\footnotetext{
'Southeast Fisheries Center Beaufort Laboratory, National Marine Fisheries Service, NOAA, Beaufort, NC 28516.

${ }^{2}$ Department of Zoology, North Carolina State University, Raleigh, NC 27607
}

Pagrus sedecim Ginsburg 1952:93, Pensacola, Fla.

\author{
1.2 Taxonomy \\ 1.21 Affinities

$\begin{array}{cc}\text { Phylum } & \text { Chordata } \\ \text { Class } & \text { Osteichthyes } \\ \text { Order } & \text { Perciformes } \\ \text { Suborder } & \text { Percoidei } \\ \text { Family } & \text { Sparidae } \\ \text { Genus } & \text { Pagrus } \\ \text { Species } & \text { Pagrus pagrus }\end{array}$

Generic

The generic description follows Fowler (1936): "Body oblong, compressed. Head large. Eye small. Mouth rather small, terminal, low. Front teeth in jaws cardiform, outer series usually enlarged, canine-like, not compressed; teeth behind canines slender and acute; both jaws with 2 or 3 series of rounded molar teeth, sometimes irregularly mixed with slender teeth; no teeth on vomer or palatines. Hind nostril oblong. not slitlike, much larger than anterior. Preorbital deep. Preopercle entire. Opercle not armed. Gill rakers short. Branchiostegals 6. Air vessel simple. Intestinal canal short. Pyloric appendages short. Scales moderately large. Dorsal rather low, spines 11 or 12 , depressible in groove; rays 10 or 11 . Anal spines 3, moderate, rays 8 . Caudal forked."

Another important generic character is: ". . . dorsal fin not preceded by a projecting spine (present in Calamus, but largely hidden by skin and scales)..." (Randall 1968).

Four valid species of Pagrus are presently recognized, two from the eastern Atlantic $P$. auriga and $P$. ehrenbergi, one from both eastern and western Atlantic, $P$. pagrus (Fig. 1), and one species from the Indo-Pacific ( $P$. major). Briefly, the geographical range for each species is as follows:

Pagrus pagrus (Linnaeus)-Eastern Atlantic from the 


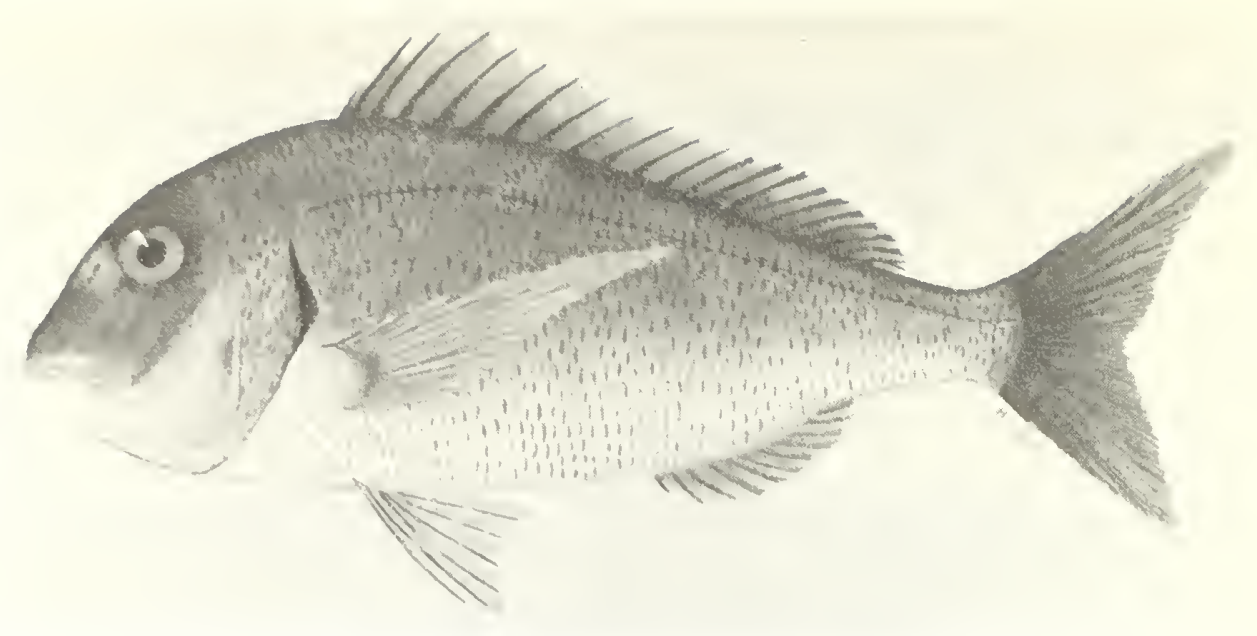

Figure 1.-Red porgy, Pagrus pagrus, approximately $425 \mathrm{~mm}$ total length caught off North Carolina (drawing by Herberg Gordy, NMFS).

British Isles, Azores and Canary Islands south to Angola; western Atlantic from New York south to Argentina; includes the Gulf of Mexico but not the West Indies or Central America.

Pagrus auriga (Valenciennes)-Eastern Atlantic from Madeira and the Canary Islands to Guinea.

Pagrus ehrenbergi (Valenciennes)-Eastern Atlantic and Mediterranean, south to Angola.

Pagrus major (Temminck and Schlegel)-Yellow Sea, Sea of Japan; on the Pacific coast of Japan from Hokkaido southward; East and South China seas southward to Australia and in the Indian Ocean.

\section{Specific}

Dorsal fin rays $12-13$ (usually 12 ), $9-11$ (usually 10 ); anal fin rays $3,7-9$ (usually 8 ); lateral-line scales 51-59; total first-arch gill rakers $13-17$, usually $6+1+9=16$; pectoral rays 14-16; vertebrae $10+14=24$; branchiostegal rays 6 . Body moderately deep, depth 2.59 to 2.93 times in standard length (SL); pectoral fin 2.59 to 3.50 times in SL; head 2.76 to 3.60 times in SL; eye diameter 2.77 to 5.48 times in head; nostril width 1.05 to 4.25 in nostril length; caudal peduncle depth 8.11 to $10.92 \%$ SL; maxillary with cleft midlaterally; length of head 0.8428 to 0.8821 in head depth; head length 0.2585 to 0.2829 in distance from the base of the orbit to the jaw articulation (depth of cheek). Meristics and proportional measurements are from Manooch et al. 1976.

Both eastern and western Atlantic specimens are colored similarly, although the heads of eastern Atlantic porgy are darker, particularly after preservation. Overall body color in life is reddish above and silver-white below. When stressed, fish become barred with 5 to 6 red, vertical bands. There are 11 to 12 rows of small blue spots occurring from the nape region to the caudal peduncle and extending ventrally to just below the base of the pectoral fin. Ventrally, the fish are white to gray-white.
There are generally two light blue laterally directed streaks, one just above, and one just below the eye. The nostril and maxillary areas are silver-blue (metallic). The eye consists of a yellow iris and a black pupil. The ventral fins in life are light blue, but fade to white-gray upon death. The pectoral fins are light yellow. The caudal fin is also light yellow shading to red at its posterior edge. The spiny dorsal fin is pink and the soft dorsal is yellow. Underwater, western Atlantic specimens appear uniformly silver-white with the blue spots evident. A dark band runs from just below the eye to the articulation of the jaw. Preserved specimens appear dull, yellow-brown. The blue, red, and distinct yellow colors are no longer evident on the fins. The spots are still visible, but are black or brown (modified from Manooch et al. 1976).

\subsection{Taxonomic status}

Ginsburg (1952) concluded that the form found in the western Atlantic was a separate species, Pagrus sedecim, from that in the eastern Atlantic on the basis of number of pectoral rays, relative depth of the caudal peduncle, and presence of blue spots. Ginsburg's small sample sizes and examination of eastern and western Atlantic specimens in the U.S. National Museum of Natural History prompted Manooch et al. (1976) to review the status of Pagrus sedecim Ginsburg. Specimens of eastern Atlantic Pagrus pagrus were collected from the Canary Islands, Spain, and those of nominal P. sedecim were collected off North Carolina and in the Gulf of Mexico. Meristics, proportional measurements, and electrophoresis were used to evaluate whether $P$. sedecim was a separate species. Results indicated intraspecific differentiation; therefore, $P$. sedecim was placed in the synonomy of $P$. pagrus, and eastern and western Atlantic porgy were considered to represent populations of a 
single species. Cotrina and Cousseau ${ }^{3}$ examined 150 specimens from Mar del Plata, Argentina, and found no significant difference in meristics or morphometrics compared with eastern Atlantic (European) fish. Also, Travassos (1973), working with red porgy from Brazil, found no basis for the species division of eastern and western Atlantic fish as proposed by Ginsburg (1952).

1.23 Standard common names, vernacular names.

United States-Red porgy, Pink porgy, Silver snapper, Rose perch

Canary Islands-Bocinegro, Bocanegra, Besugo

Madeira-Pargo

Senegal-Debesjhal

Mauritania, Spanish Sahara-Lauriana

France-Pagré

British Isles-Sea bream

Italy-Pagri, Pargo

Poland-Pagrus, Rodzaj pagrusy

Brazil-Pargo róseo

Uruguay-Pargo colorado, Besugo

Argentina-Besugo

Spain-Pargo

Libya-Mamrya

Malta-Pagru

Tunisia-Hamraia, Gerali

Turkey-Mercan

Portugal-Pargo

Israel-Shefarnun

Yugoslavia-Pager

Greece-Fagri

\subsection{Morphology}

\subsection{External morphology}

Manooch et al. (1976) derived a series of proportional body measurements and meristic counts from approximately 80 specimens from the Canary Islands, Gulf of Mexico, and North Carolina (Table 1). These data made it possible to compare the meristics and morphometrics of fish from three different geographical areas.

\subsection{Protein specificity}

Manooch et al. (1976) used two types of electrophoretic procedures-regular disc gel and sodium dodecyl sulfate - to try to find differences among 11 species of sparids. Those analyzed were: Pagrus pagrus, nominal $P$. sedecim, $P$. auriga, Pagellus acarne, $P$. erythrinus, $P$. mormyrus, Dentex filosus, $D$. macrophthalmus, Diplodus sargus, Calamus leucosteus, and $C$.

${ }^{3}$ Cotrina, C. P., and M. B. Cousseau. Undated. Informe sobre el muestreo bioestadistico do desembarque de pescado en el Puerto de Mar del Plata, Argentina. Periodo Enero de 1972-Diciembre de 1974. Instituto de Biologia Marina, Mar del Plata, Argentina. Unpaged.
Table 1.-Mean meristic and proportional measurements of 11 characters tested by discriminant function analysis differentiating between three areas of collection (from Manooch et al. 1976).

\begin{tabular}{|c|c|c|c|}
\hline \multirow[b]{2}{*}{ Character tested } & \multicolumn{3}{|c|}{ Collection site } \\
\hline & $\begin{array}{c}\text { North } \\
\text { Carolina } \\
\text { (25) }\end{array}$ & $\begin{array}{c}\text { Gulf of } \\
\text { Mexico } \\
\text { (13) }\end{array}$ & $\begin{array}{c}\text { Canary } \\
\text { Islande } \\
(42)\end{array}$ \\
\hline Dorsal rays & 9.96 & 9.92 & 9.98 \\
\hline Anal rays & 8.00 & 8.08 & 8.02 \\
\hline Pectoral rays & 15.84 & 15.92 & 15.21 \\
\hline Lateral-line scales & 54.92 & 54.61 & 53.88 \\
\hline Gill rakers & 15.60 & 15.61 & 15.93 \\
\hline SL/depth & 2.70 & 2.64 & 2.67 \\
\hline SL/pectoral length & 2.90 & 2.79 & 2.79 \\
\hline $\mathrm{SL} /$ head & 3.15 & 3.01 & 3.15 \\
\hline Head length/eye diameter & 3.95 & 3.68 & 3.67 \\
\hline Nostril length/nostril width & 2.48 & 2.34 & 2.60 \\
\hline Caudal peduncle depth/SL & 9.14 & 9.92 & 9.66 \\
\hline
\end{tabular}

nodosus. By using both electrophoretic techniques they found distinct differences among all pairs except $P$. pagrus and $P$. sedecim.

\section{DISTRIBUTION}

\subsection{Total area}

Red porgy is a sublittoral, demersal, marine species which occurs to deep zones of continental shelves. The species is found in the eastern Atlantic from the British Isles (occasionally) south to Angola off the west coast of Africa, in the Azores and Canary Islands, and in the Mediterranean and Adriatic (Hilgendorf 1888; Fowler 1936; Soljan 1963; Ranzi 1969). Red porgy also occur in the western Atlantic and Gulf of Mexico ranging as far north as New York (occasionally) south to Argentina (Randall 1968); the species has not been reported from the Caribbean or Central America (Fig. 2).

Red porgy are commonly found at depths ranging from 18 to $183 \mathrm{~m}$. Off northwest Africa, Murray and Hjort (1912) reported fishermen capturing Pagrus pagrus in waters ranging from 33 to $55 \mathrm{~m}$. Exploratory trawling by the Poles produced red porgy in depths ranging from 22 to $150 \mathrm{~m}$ (Wozniak 1967; Klimaj 1970). The deepest collection site recorded is $280 \mathrm{~m}$, south of the Canary Islands (Murray and Hjort 1912). Bottom water tem. peratures around the Canary Islands and on the West African Continental Shelf range from $15^{\circ}$ to $20^{\circ} \mathrm{C}$ annually (Jones and Folkard 1970). Wheeler (1969) described the habitat of $P$. pagrus in the Mediterranean and Atlantic off North Africa: "A sea bream most commonly found on gravel bottoms or around rocks, in depths up to 33 fathoms $(60 \mathrm{~m})$, but young specimens can be caught near the shore within the normal range of the species."

In the western Atlantic, red porgy commonly occur over very irregular and low profile, hard bottom. Austin ${ }^{4}$ reported that the red porgy was the most commonly

'Austin, H. M. 1971. Ecology of fishes on Florida's Middle Ground. Fla. State Univ., Dep. Oceanogr., Tallahassee, Fla., 56 p. 


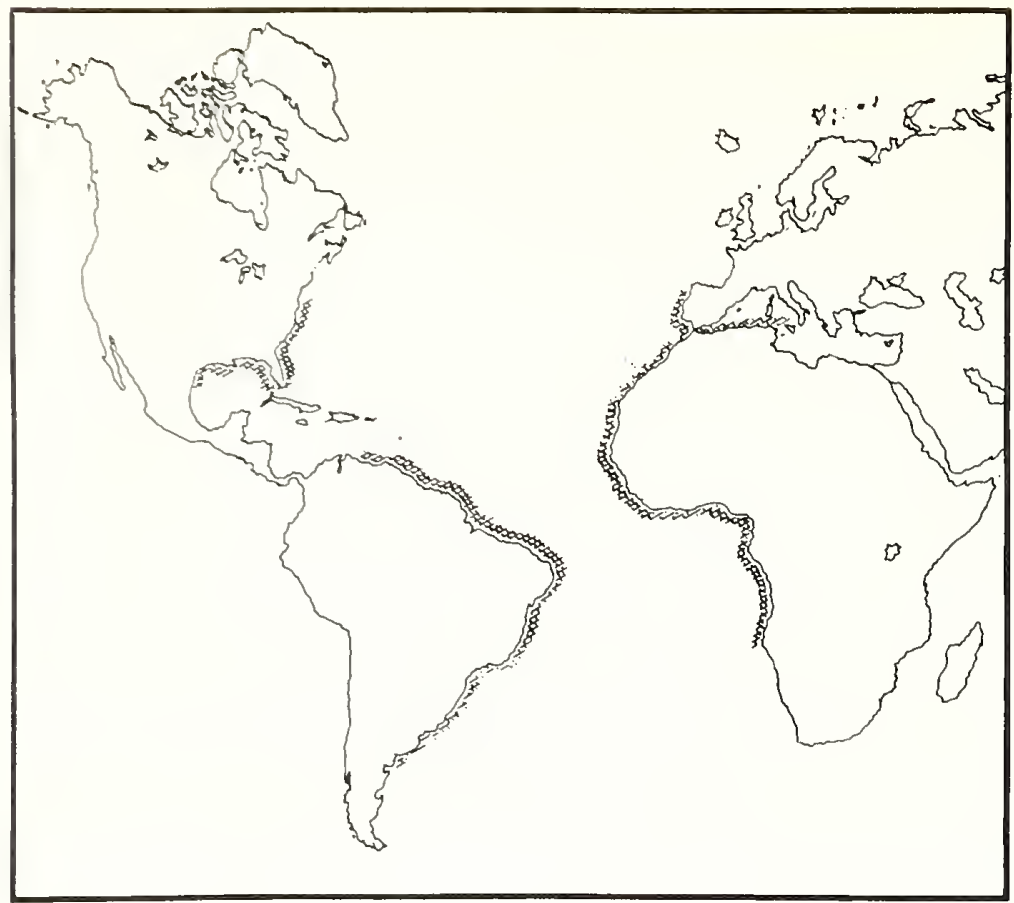

Figure 2.-Distribution of Pagrus pagrus.

caught species on the Florida Middle Ground, an area in the Gulf of Mexico off Tampa. The habitat is characterized by a flat, sandy bottom in $40 \mathrm{~m}$ of water with limestone outcroppings rising $15 \mathrm{~m}$ off the bottom. Bottom water temperatures ranged from $13^{\circ}$ to $25^{\circ} \mathrm{C}$. Manooch (1975) described the habitat of red porgy off North Carolina and South Carolina. Red porgy were caught by hook and line over several types of habitat, e.g., open-shelf, live-bottom, shelf-edge, and lower shelf, but were concentrated over inshore, live-bottom areas, and at the shelf-edge where the bottom is characterized by a series of troughs, terraces, and ridges which parallel the shelf dropoff (Macintyre and Milliman 1970). The inshore concentrations occurred from 24 to $42 \mathrm{~m}$, and offshore from 51 to $128 \mathrm{~m}$. Inshore, red porgy and related species are usually found associated with any irregularity: shipwrecks, rock outcroppings, and small patches of coral (Huntsman and Macintyre 1971), on the otherwise smooth, sandy bottom live-bottom as defined by Struhsaker (1969). Bottom temperatures, including both inshore and offshore, range from approximately $14^{\circ}$ to $25^{\circ} \mathrm{C}$ annually (Manooch 1975 ).

In South American waters red porgy are also found over rough bottom in depths similar to the North American distribution. N. A. Menezes (pers. commun., Museu de Zoologia da Universidade de São Paulo) reported the species occuring from 19 to $144 \mathrm{~m}$ off Brazil and Uruguay, and Cotrina and Cousseau (see footnote 3 ) stated that $P$. pagrus seldom occur deeper than $37 \mathrm{~m}$ off Mar del Plata, Argentina. M. Yesaki (pers. commun., SUDEPE/PDP, Rio Grande) found red porgy concentrated in the mixing area of the cold Falkland Current and the warm Brazil Current $\left(13^{\circ}-18^{\circ} \mathrm{C}\right)$ off Brazil during 1973, and S. S. Cordeiro and A. Miyares (pers. com- mun., Programa de Pesquisa ex Desenvolvimento Pesqueiro do Brasil) stated that Pagrus commonly occured at 40 to $59 \mathrm{~m}$ off the southern coast of Brazil.

\subsection{Differential distribution}

\subsection{Eggs, larvae, and juveniles}

Studies of early life stages of the red porgy have been hampered by the difficulty of identification at the species level; this has been particularly true in North America. Manooch (1976) provided a basic description of the spawned, unfertilized egg for fish collected off North Carolina. Descriptions of eggs, larvae, and prejuveniles are provided by Ranzi (1969) and Ciechomski and Weiss (1973) for eastern Atlantic and South American stocks, respectively. Since the eggs and larvae are pelagic for a number of days, their distribution is greatly influenced by currents and winds.

Ranzi (1969) referred to vertical migration of larval and postlarval phases of Pagrus pagrus: "All of these stages [ $<10 \mathrm{~mm}]$ can be fished in the deep plankton but at 10 $\mathrm{mm}$ Pagrus comes to the surface." Also he noted a shift from planktonic to benthic existence at lengths above 20 $\mathrm{mm}$.

It is highly probable that young Pagrus are distributed inshore of adult populations. Manooch (1975) reported young-of-year trawled from $9 \mathrm{~m}$ off Charleston, S.C. Even though they may occur inshore as juveniles, adverse conditions of low water temperature, competitive exclusion, and unsuitable substrate reduce the longevity of this inshore distribution.

Not only are eggs and larvae transported inshore by Ekman transport, but they are probably transported for 
relatively long distances. Manooch et al. (1976) proposed a hypothesis explaining population similarities of eastern Atlantic and western Atlantic Pagrus pagrus: "... although the populations have been separated a long time sufficient gene flow has occurred to prevent divergence. Passive transport of larvae from Africa is considered a probable mechanism for maintaining gene flow between the eastern and western Atlantic stocks."

\subsection{Adults}

Adult red porgy occupy a wide horizontal and vertical range (section 2.1), preferring hard substrate, both low and high profiles, and do not display marked seasonal movements. Adults do not occur in waters as shallow as larvae and juveniles but the inshore occurrence of young is probably short-lived (section 2.21). Adults do not occur at great depths under the upper layers which apparently transport eggs and larvae.

\subsection{Determinants of distribution}

Substrate: hard bottom; low and high profile. Depth: 9 to $280 \mathrm{~m}$. Temperature: $13^{\circ}$ to $26^{\circ} \mathrm{C}$.

\section{BIONOMICS AND LIFE HISTORY}

\subsection{Reproduction}

\subsection{Sexuality}

Both protandrous and protogynous hermaphroditism are relatively common among the sparids (D'Ancona 1950). D. S. Beaumariage (pers. commun., Florida Department of Natural Resources) reported red porgy collected off the west coast of Florida appear to display protogynous hermaphroditism, although data at present are insufficient for quantitative description. Manooch (1976) reported that a predominance of females at smaller size intervals $(<400 \mathrm{~mm}$ total length (TL)), a large proportion of males for the larger size intervals ( $>450 \mathrm{~mm}$ TL), and discovery of individuals with both testicular and ovarian tissue supports the theory of protogyny. Functional hermaphroditic fish were collected off the Carolinas.

\subsection{Maturity}

Manooch (1976) determined age at sexual maturity for female red porgy. The correlation of age with maturity suggests that none of the age I fish, $37 \%$ of the age II fish, $81 \%$ of age III fish, and $100 \%$ of the age IV fish were mature.

\subsection{Fertilization}

Fertilization is external.

\subsection{Gonads (ovaries)}

Manooch (1976) evaluated three predictors of fecundity from 50 fish: total length, weight, and age. All three variables could be used to predict fecundity, but weight of fish proved to be the best predictor. The equation describing the relationship and coefficient of determination is:

$\operatorname{Ln}$ fecundity $=1.7369+1.5178($ Ln weight $), r^{2}=0.70$.

The $95 \%$ confidence limits are also presented (Fig. 3 ). Point estimates of fecundity ranged from 48,660 eggs for a fish $304 \mathrm{~mm}$ TL and weighing $390 \mathrm{~g}$, to 488,600 ova for a female measuring $516 \mathrm{~mm}$ TL and weighing $1,783 \mathrm{~g}$. Theoretically, a $600-\mathrm{mm}$ red porgy could produce approximately 943,000 eggs if maximum ova production is not obtained at a smaller size (age).

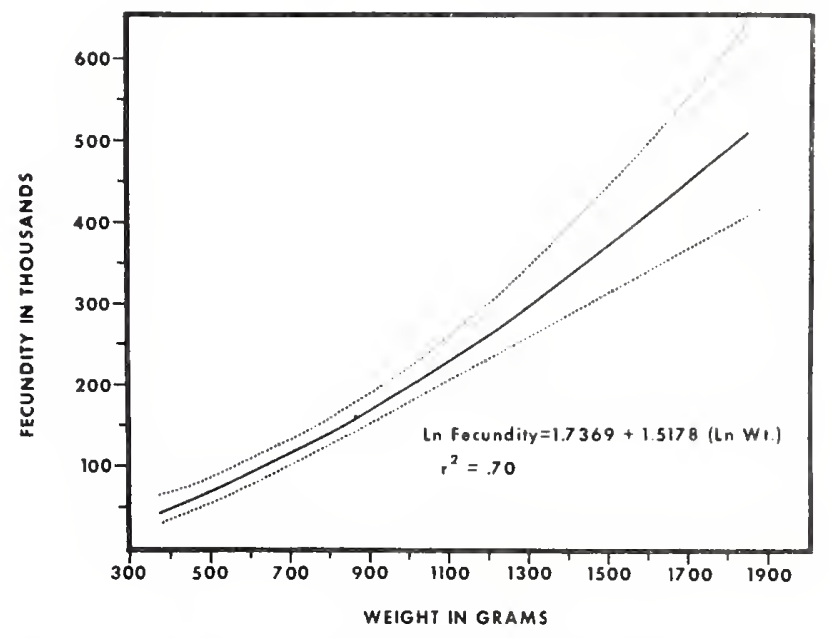

Figure 3.-Relationship between fecundity and fish weight for 50 red porgy collected from Onslow Bay, N.C. (from Manooch 1976).

\subsection{Spawning}

In their study of egg and larval development, Ciechomski and Weiss (1973) referred to red porgy spawning in the Argentine Sea mainly from December through January when the water temperature range approximated $20^{\circ}$ to $21^{\circ} \mathrm{C}$. Ranzi (1969) mentioned the period of sexual maturity of $P$. pagrus off Algiers as April to June. Manooch (1976) collected ripe females from Raleigh and Onslow Bays, N.C., over irregular bottom from January through April in water ranging in depth from 21 to $100 \mathrm{~m}$. Bottom temperatures varied from $16.4^{\circ}$ to $21.5^{\circ} \mathrm{C}$. Peak spawning occurred from March through April. Gonad condition was believed to be more closely associated with photoperiod than bottom water temperature (Fig. 4). Early maturing and ripe stages of testes were easily discernible, but the late maturing and ripe classes were difficult to separate. Milt could be pressed from the central canal of testes from January through April. 

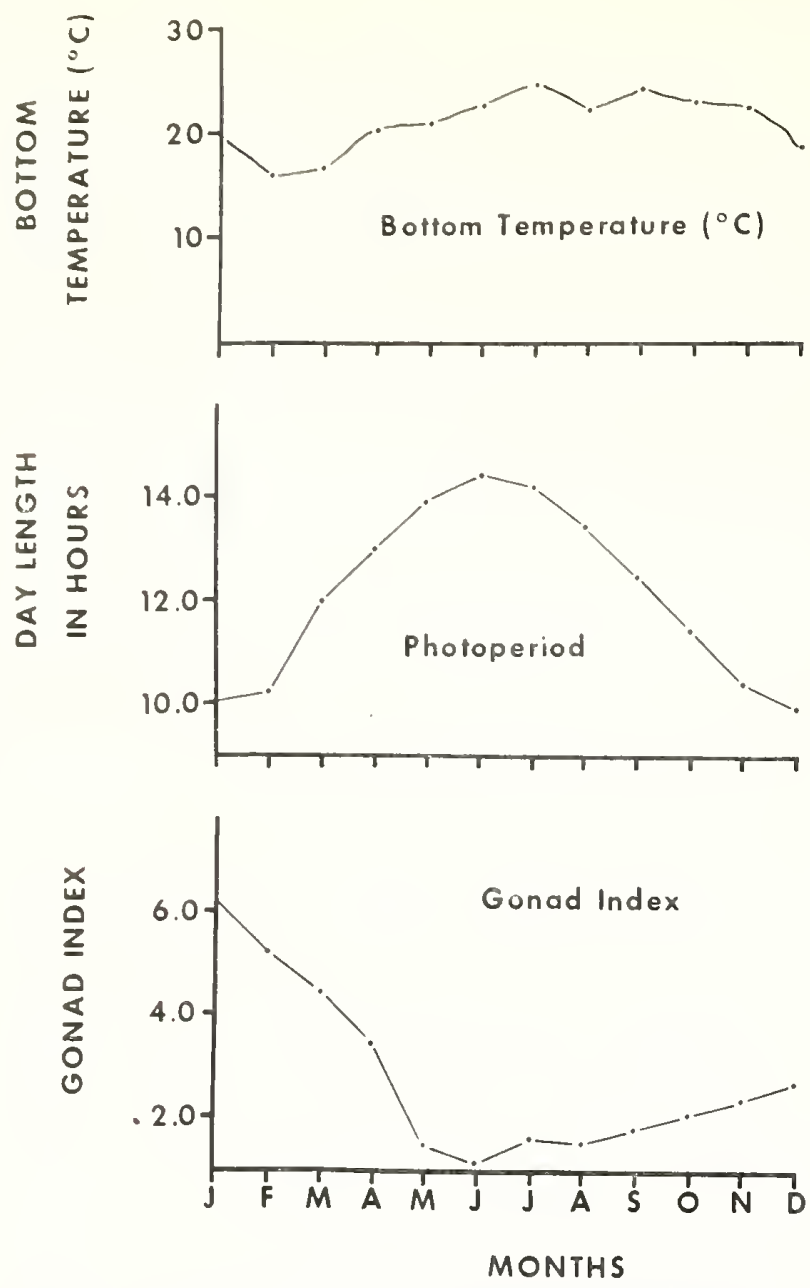

Figure 4.-Mean monthly gonad indices for female Pagrus pagrus for each month compared with photoperiod and bottom temperature (from Manooch 1976).

\subsection{Eggs}

Ripe, unfertilized red porgy eggs were pelagic, spherical, without appendages, measured 0.64 to 0.92 $\mathrm{mm}$ in diameter, and contained a single oil droplet which measured 0.20 to $0.32 \mathrm{~mm}$ in diameter (Manooch 1976). Ciechomski and Weiss (1973) described fertilized eggs which measured 0.81 to $0.88 \mathrm{~mm}$ in diameter with an oil droplet which measured 0.18 to $0.21 \mathrm{~mm}$ in diameter.

\subsection{Preadult phase}

\subsection{Embryonic phase}

A description of embryonic development is translated from Ciechomski and Weiss (1973) from the Argentine Sea (Fig. 5): The perivitelline space was small and emphasized at the two poles. Two hours after fertilization 16 to 32 blastomeres were observed in the animal pole. The oil droplet was positioned close to the vegetal pole and aided with flotation as the eggs floated close to the water surface. After $5 \mathrm{~h}$ a blastula with medium cells formed;
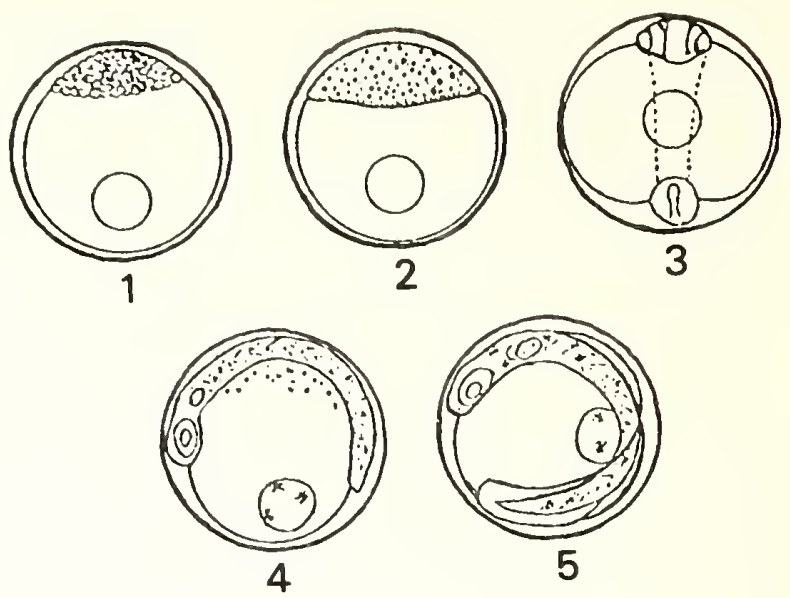

5
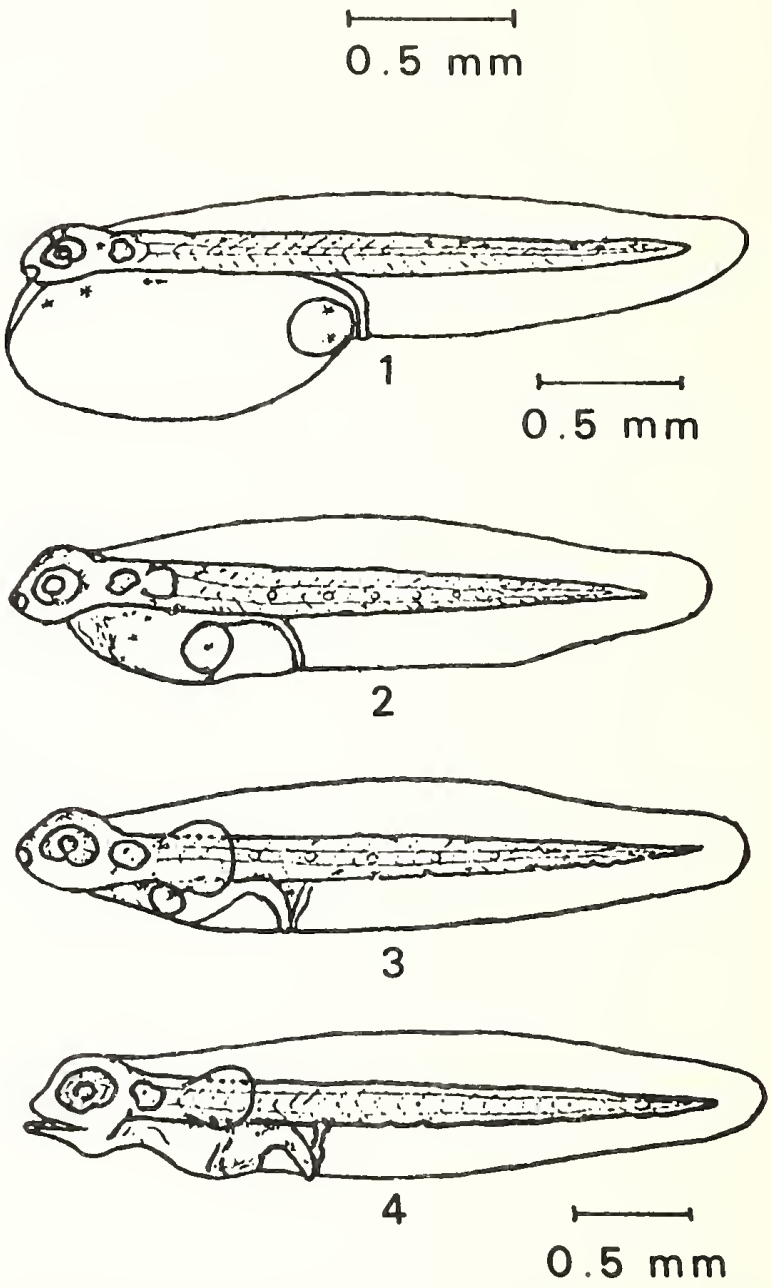

Figure 5.-Larval stages of red porgy from fertilized egg to 4 days after hatching (from Ciechomski and Weiss 1973).

at 8 to $8 \frac{1}{2} \mathrm{~h}$ gastrulation began. In this stage the germinal ring was evident; the embryo was similar to other species of teleosts and started to increase in size. Morphometric changes were rapid and the otic capsules, first myomeres, and brainfolds could be noted. After 17 to 18 $h$, the embryo occupied the first half of the egg diameter 
and its posterior paris began to grow independently from the yolk sac. The first pigmentary cells appeared as small black points distributed along the body and yolk sac. After $21 \mathrm{~h}$, the embryo occupied about two-thirds of the egg's diameter and the optic capsules were formed. The number of myomeres and pigment cells increased, especially in the zone close to the optic capsules and in the caudal region. Twenty-six hours after fertilization, the embryo occupied two-thirds of the perimeter of the egg and the otoliths were visible in the otic capsule. Hatching occurred from 28 to $38 \mathrm{~h}$ after fertilization (temperature, $21.5^{\circ}$ to $22.5^{\circ} \mathrm{C}$ ).

\subsection{Larval phase}

The following is a description of larvae from hatching to 4 days (Ciechomski and Weiss 1973). The recently hatched larvae measured $2.42 \mathrm{~mm}$ and were almost transparent. The yolk sac was large and oval shaped. In most larvae the oil drop was situated in the posterior portion of the yolk sac, but in a few it was found in the center. The anus was located behind the yolk sac in the middle of the body. The digestive tract opened at the anus at a right angle. The fin fold originated behind the head and was continuous to the anus. All capsules, otic, optic, and olfactory, were evident. The same distribution of pigment for all larvae of the same stage was typical for the species. The yellow cells were distributed along the body in five bands. At 1 day the larvae were $3.1 \mathrm{~mm}$, and at 2 days $3.25 \mathrm{~mm}$. When the larvae were $21 / 2$ days old the mouth was functional.

Ranzi (1969) described larval and juvenile phases of $P$. pagrus from the Bay of Naples. Specimens collected were pelagic until $20 \mathrm{~mm}$ and then shifted to the bottom. Brief descriptions for fish 3.2 to $15 \mathrm{~mm}$ follow.

$3.2 \mathrm{~mm}$-The tail was a little more than twice as long as the body; the maximum height was contained ca. 3.5 times in the length. General shape of the body was rathei slim. The unpaired fin was continuous and the caudalmost area revealed some visible outlines of rays, not perceived in the area of the anal and dorsal. Of the paired fins, only the pectorals were present. On the operculum, a series of spines, typical of later stages, was evident represented by protruding crests. There was no occipital crest. The eye was pigmented, the intestine enlarged anteriorly, bent ventrally, terminated in the anus, and opened at the level of the 10th and 11th myomere.

$4.1 \mathrm{~mm}--$ The specimen had features of small Pagrus; that is, the tail became larger than in the previous stage with respect to the body, accounting for almost twothirds of its length, while the head became very powerful; the maximum depth was thus contained only 3 times in the length. The anus had moved in the rostral direction and was located at the level of the seventh myomere. On the operculum two series of spines had developed, the posterior more developed with a very long central spine located at the angle where the whole series bent in the dorsal direction. Dorsally to the eye there was a crest with two slight indentations, and a preliminary outline of spines. On the dorsal profile, just behind the head, there was a strong unpaired spine, typical of young Pagrus from this stage up to the length of $15 \mathrm{~mm}$; the belly, caudally to the operculum, had another strong unpaired spine.

$8 \mathrm{~mm}$-The tail was half as long as the body. The supraorbital crest had four small teeth; the inner opercular crest had seven short spines and the outer crest eight spines, the fifth the longest. The ventral fins were formed but there were no outlines of rays; the unpaired fins and the pectorals had definitive rays as in the adult: D $12 / 10 ;-A 3 / 8 ;$ C $17 ; \mathrm{P} 15$. The anal was prolonged in front of the rays by a membranous portion and reached the anus.

$9 \mathrm{~mm}$-This specimen was similar to the one at $8 \mathrm{~mm}$. All the previous stages could be fished in the deep plankton but at $10 \mathrm{~mm}$ Pagrus came to the surface.

$11 \mathrm{~mm}$ - The body color was pinkish-yellowish. Its dorsoventral diameter increased less than the length and was $2.2 \mathrm{~mm}$ in the cephalic region, which accounted for one-fifth of the length. In the scapular region a series of short spines appeared. The definitive rays were evident in the ventrals.

$13 \mathrm{~mm}$-Transverse stripes appeared. The first eight rays of the dorsal, all the rays of the ventrals, and the three spiny rays of the anal were yellow. Scales appeared on the body.

$15 \mathrm{~mm}$-The lateral line of the trunk, convex upward fairly near the dorsal profile, was evident. The supraorbital crest was less visible than in the previous stages. The whole body was covered with scales. Dorsally and just behind the head, the occipital spine was still present, which up to this stage is typical of small Pagrus (Fig. 6).

\subsection{Adult phase}

\subsection{Longevity}

Red porgy are slow growing and have a relatively long life span. Although the species may attain an age of $15 \mathrm{yr}$ or older (Manooch and Huntsman 1977; Cotrina and Cousseau see footnote 3 ), apparently rapid total annual mortality occurs after age XI off the southeastern United States. From 1972 through 1974, NMFS personnel examined over 13,000 red porgy landed by recreational fishermen fishing from North Carolina and South Carolina headboats. Fish aged IV to VIII were common in the catch (Manooch 1975) (Fig. 7).

\subsection{Hardiness}

No quantitative data are available on the tolerance of red porgy to marked changes in the environment. Personal experiences with the species allow us to conclude that $P$. pagrus is perhaps the hardiest of the demersal fishes which inhabit the outer continental shelf off North Carolina and South Carolina. Red porgy have been taken from depths of $>100 \mathrm{~m}$, tagged, and then recaptured later with no obvious ill effects caused by pressure difference. In holding tanks, red porgy have undergone rather dras- 


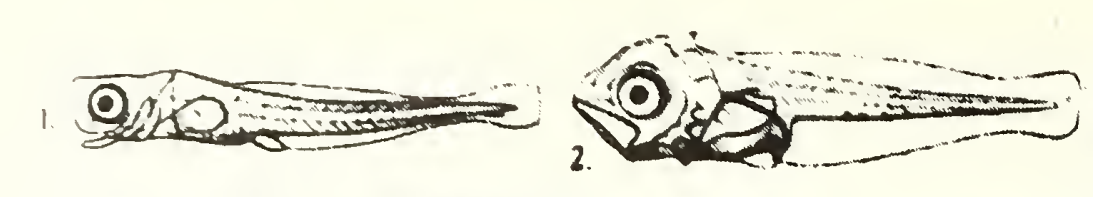

3.
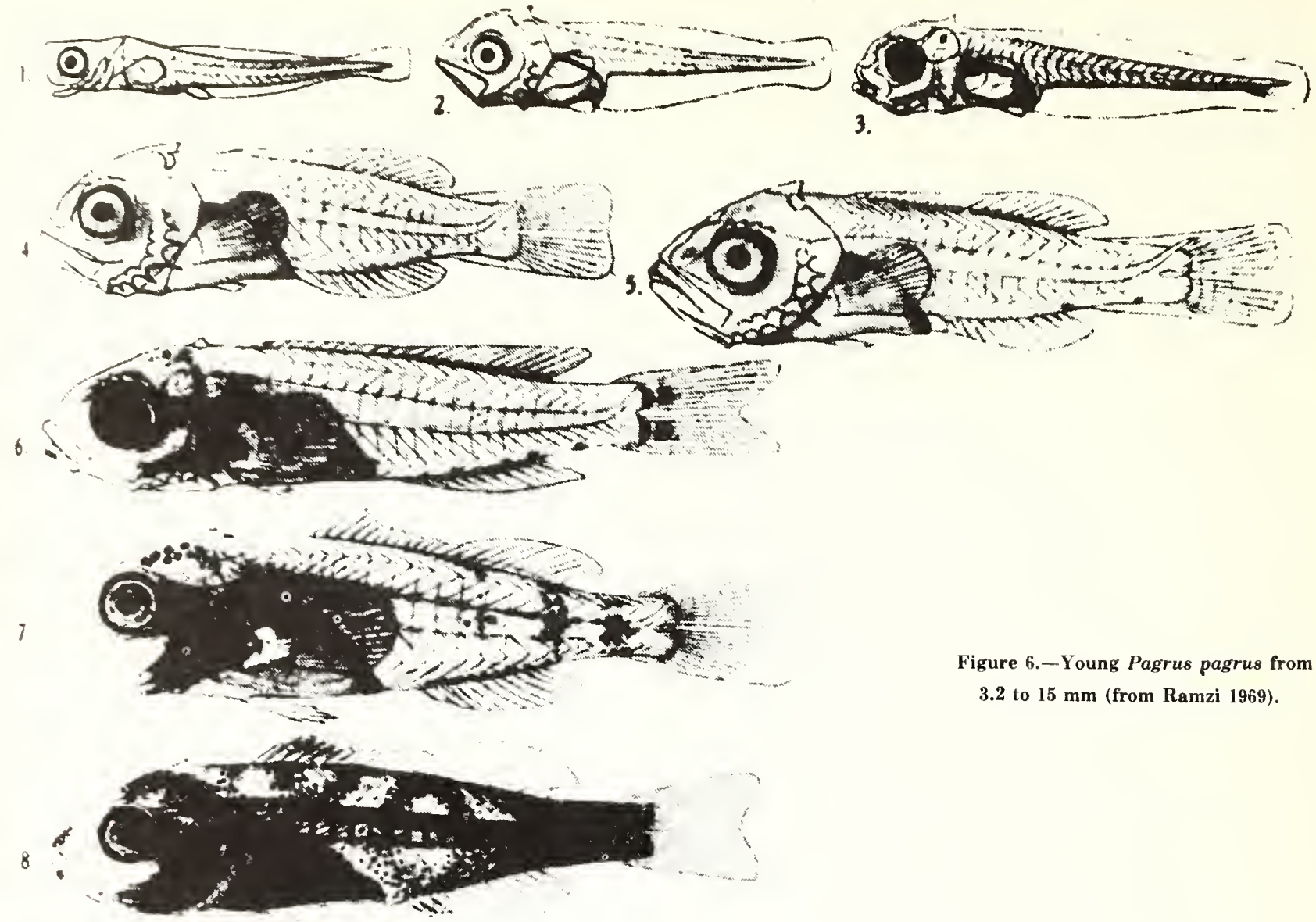

Figure 6.-Young Pagrus pagrus from 3.2 to $15 \mathrm{~mm}$ (from Ramzi 1969).

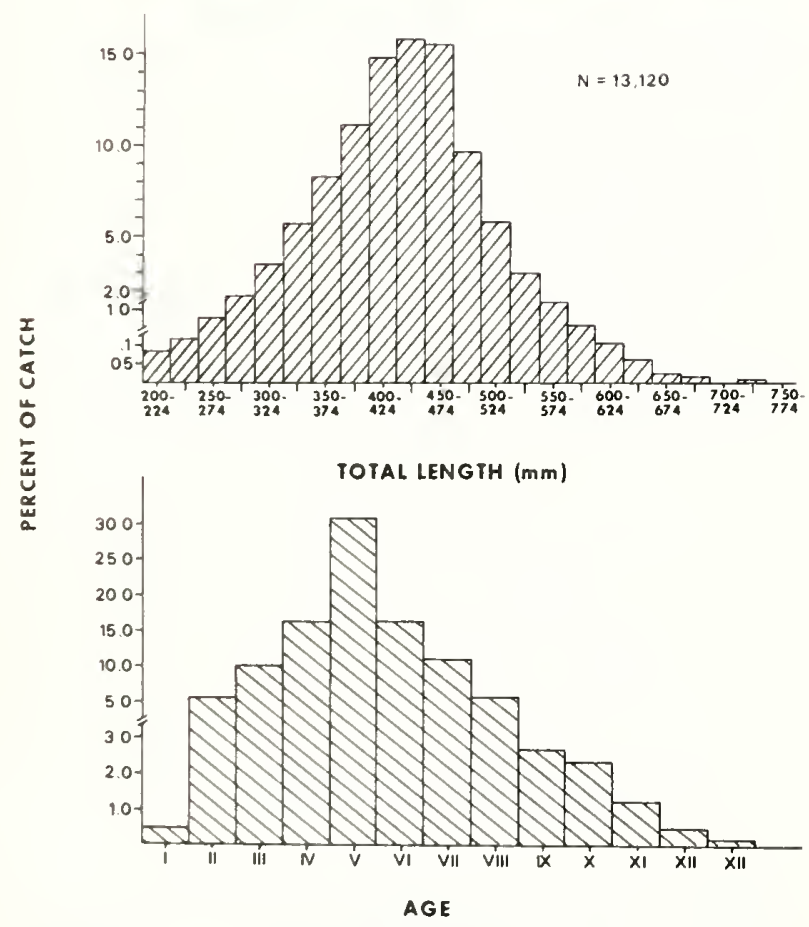

Figure 7.-Age and length distributions for 13,120 red porgy sampled from the Carolina headboat fishery (from Manooch 1975). tic changes in temperature, over relatively short periods of time. Changes from $8.0^{\circ}$ to $29.1^{\circ} \mathrm{C}$ have not proven fatal (R. O. Parker, pers. commun., National Marine Fisheries Service, Beaufort, N.C.).

\subsection{Competitors}

Any fish which feeds on similar foods and occupies the same habitat with the red porgy could be considered a competitor. Considering the wide distribution of $P$. pagrus, the list of competitive fish could of course, be very extensive. Off northwest Africa, other sparids could be major competitors: Dentex, Pagellus, Diplodus, Sparus, and Pagrus are some of the genera. In North Carolina and South Carolina, species of serranids, lutjanids, pomadasyids, and branchiostegids are major competitors for food and, to an extent, space.

\subsection{Predators}

All large carnivorous sea mammals, turtles, and fishes which occur with red porgy are potential predators. Red porgy remains have been identified in stomachs of sharks, barracuda, and greater amberjack (personal observation). 
3.35 Parasites, disease, injuries, and abnormalities

There is little published information on parasites and diseases of red porgy. Sproston (1946) listed three species of monogenetic trematodes found on the gills of $P$. pagrus: Anoplodiscus richiardii (from the Mediterranean), Diplectanum echineis (from Trieste), and Microcotyle archosargi (from North America, Atlantic). Causey (1953) identified the copepod Lernanthropus brevoortiae Rathbun on a fish thought to be Pagrus sedecim from the Texas coast.

\subsection{Nutrition and growth}

\subsection{Feeding}

The red porgy is an opportunistic browser which feeds on a tremendous variety of invertebrates as well as small fishes. Manooch (1975) described some aspects of red porgy feeding: "They are fast enough to compete successfully with other fish for such motile foods as small fish, portunid crabs, squids, and shrimp. Also, $P$. pagrus possesses strong molariform teeth which enable it to crush less motile, armored forms such as echinoderms, pagurid crabs, and gastropods. The red porgy, then, seems well adapted to feed on motile forms and also on non-motile organisms which must depend on armour as a protection against predation. Both observations made in large aquaria, and experimental fishing reveal the red porgy to be very agressive feeders. They generally seize the food (or bait) immediately when it is presented to them." Manooch (in press) also noted that the red porgy is a bottom feeder: "Approximately $74 \%$ of the foods were classified as obligate benthic organisms; $60 \%$ by volume. If semibenthic organisms are included, the percentages are increased to 90 to 92 respectively."

\subsection{Food}

As mentioned above (section 3.41) red porgy feed on a variety of invertebrates and small fishes. Wheeler (1969) reported that the diet of Pagrus pagrus collected in the eastern Atlantic "... consists principally of fish and crustaceans, including crabs, shrimps and prawns. On broken ground large specimens eat quantities of octopus." In the western Atlantic, Bearden and McKenzie (1969) mentioned decapods (Majidae, Xanthidae, and Portunidae), polychaetes, and mollusks in the diet of fish collected off South Carolina, and Austin (see footnote 4) found crabs (Mithrax pleuracanthus and Stenorynchus seticornis), ophiuroids, and mollusks in stomachs of red porgy collected from the Gulf of Mexico. Red porgy collected from Argentine waters fed on fishes, mollusks, crabs, sessile coelenterates, polychaetes, amphipods, and echinoderms (Cotrina and Cousseau see footnote 3 ). Manooch (in press) found 69 different food items in red porgy stomachs collected off North Carolina and South Carolina including 14 species of fishes and 55 taxa of in- vertebrates. Invertebrates, represented primarily by crustaceans, mollusks, and echinoderms, occurred in $89 \%$ of the stomachs. Crabs, mainly majids, portunids, and calappids, were the predominant food by both frequency of occurrence and volume. Little difference in the diet was noted between seasons, area of collection, or depth. The diet of juveniles $(46-64 \mathrm{~mm})$ varied significuntly from adults: these smaller fish consumed amphipods, copepods, stomatopods, isopods, and annelids.

\subsection{Growth rate}

Age and growth has been determined for red porgy collected from North Carolina and South Carolina waters (Manooch and Huntsman 1977). Average lengths for 1,777 red porgy aged by scales collected in 1972 to 1974 were: $238,290,341,382,419,451,483,505,527,543,558$, and $604 \mathrm{~mm}$ for ages I to XII, respectively. Back-calculated lengths of 1,622 fish for ages I to XIII were: 179, $259,316,358,389,417,440,451,476,491,509,534$, and $559 \mathrm{~mm}$, respectively. The oldest fish, $15 \mathrm{yr}$, was $694 \mathrm{~mm}$ TL. Growth is more rapid the first 7 yr (Fig. 8). Observed and back-calculated length-age data were used to calculate theoretical growth. Age groups I to XII were used to fit Walford (1946) lines and the von Bertalanffy (1938) growth equation. This equation for Carolina red porgy is:

$$
l_{t}=746 \quad\left(1-\mathrm{e}^{-0.096(t+1.88)}\right) .
$$

Manooch and Huntsman (1977) also derived a lengthweight relationship for Carolina red porgy. This equation is:

$$
W=0.00002524 L^{2.8939}
$$

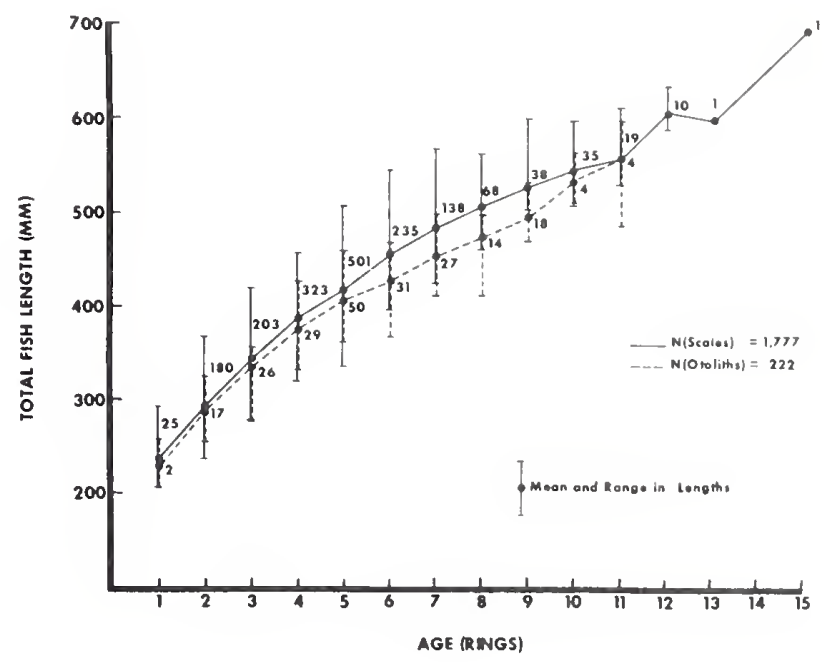

Figure 8.-Absolute growth curves for Pagrus pagrus from mean total lengths of each age group obtained by reading scales and otoliths. The number by each point on the curves represents the number of fish sampled (from Manooch 1975). 
where $W=$ weight in grams and

$L=$ total length.

The equation $W=0.000027836 L^{2.8831}$ describes the length relationship for males, and $W=0.000013378 L^{2.9954}$ is the equation for females. Dias et al. (1972) furnished lengthweight relationships for the species off South Carolina, and Cotrina and Cousseau (see footnote 3 ) provided the following length-weight regression for 1,044 specimens collected from Mar del Plata, Argentina:

$$
W=0.00002056 L^{2.897}
$$

\subsection{Behavior}

\subsection{Migration and local movements}

Apparently, red porgy do not undergo long-range migrations, and local movements are not extensive. Trawling off the West African Continental Shelf (Wozniak 1967; Klimaj 1970) identified concentrations of Pagrus by depth and geographic area, but it could not be determined if the species migrates from one location to another. Tagging studies off the Carolinas (Manooch 1975 ) revealed that $P$. pagrus did not move far from the original tagging site. The average distance moved over a 2-yr period was $5.9 \mathrm{~km}$ and the farthest a tagged fish moved was $23.7 \mathrm{~km}$ after 47 days. Red porgy tagged and returned off of the west coast of Florida revealed no movement (Beaumariage 1969).

\subsection{Schooling}

Red porgy do occur in schools, however no quantitative data is available on school characteristics.

\section{POPULATION}

\subsection{Structure}

Since 1972, NMFS has obtained information on the sex, age, and size composition of the red porgy population off the Carolinas by regularly sampling the recreational landings. The procedures of the sampling program and catch statistics have been reported (Sekavec and Huntsman 1972; Manooch 1975; Huntsman 1976). The Instituto de Biologia Marina, Mar del Plata, Argentina, has obtained similar population characteristics by sampling commercial landings (Cotrina and Cousseau see footnote 3 ).

\subsection{Sex ratio}

The ratio of male to female red porgy landed off North Carolina and South Carolina was not 1:1 but actually 1:2.1. Of the total $705,372 P$. pagrus landed by the headboat fishery, approximately 259,638 were males and 445 ,733 were female. The percentage of males to females varied with size of fish and also by season (month). The greatest discrepancy in the ratio occurred in the spring, and was approximately 1:3. Red porgy spawn in the spring off the Carolinas, and the discrepancy between sexes caught could indicate schooling of females prior to spawning, but it is more probably due to the fact that the species displays protogynous hermaphroditism and more females are available (Manooch 1976). Commercial Argentine landings also reveal a predominance of females in the catch (Cotrina and Cousseau see footnote 3).

\subsection{Age composition}

Red porgy aged from the recreational fishery off North Carolina and South Carolina ranged from 1 to $15 \mathrm{yr}$. To facilitate analysis of data, fish were identified in age groups I to XII separately, and those few individuals XIII to XV were categorized as > XII (Manooch and Huntsman 1977).

A histogram of age frequency for 1972 to 1974 indicates that the greatest percentage of red porgy caught by the recreational fishery are age $\mathrm{V}$ (Fig. 7). For all years, $29.6 \%$ of the porgy landed were 5 -yr-old fish. Gear selectivity, rather than relative abundance of any age group, has a definite effect on age composition of the catch. This is particularly true with hook and line where smaller individuals are completely or selectively excluded from the catch.

Age $\mathrm{V}$ was the most frequently landed age group each year: $1972,32.4 \% ; 1973,28.7 \%$; and 1974, 27.4\%. A larger percentage of younger fish (I-IV) were landed in 1974 than in the other years. Whereas, in 1972 and 1973 ages VI and VII composed approximately $28 \%$ of the catch, in 1974 ages III and IV were more frequently caught than ages VI and VII.

Stratification of age frequency data by area reveals some differences in age composition. While age $\mathrm{V}$ occurred most frequently in each area, the Cape Fear, N.C., catch was composed of a larger percentage of younger fish. Twice as many age I and II red porgy were landed in the Cape Fear, N.C., vicinity as in the Cape Lookout, N.C., and Cape Romain, S.C., districts. Age IV was the next most frequently encountered age group in Cape Fear, whereas age group VI was encountered more frequently in the Cape Lookout and Cape Romain districts. As with size, the occurrence of younger fish in the Cape Fear district is probably correlated with inshore fishing intensity.

Young red porgy are more frequently caught inshore (Fig. 9). Age groups I to IV composed approximately $51.4 \%$ of the catch inshore compared with only $24.9 \%$ offshore. Hook size varied between the two grounds, and undoubtedly contributed to age composition differences of the catch. However, experimental fishing with a variety of hook sizes (1/0-9/0) aboard the research vessel indicated a predominance of larger (older) fish in deeper waters.

Red porgy aged by scales from Argentina ranged from 0 to $17 \mathrm{yr}$ (Cotrina and Cousseau see footnote 3 ). Percentages by age for more than 6,500 fish from commercial trap and trawl landings, 1972 to 1974 were: age 


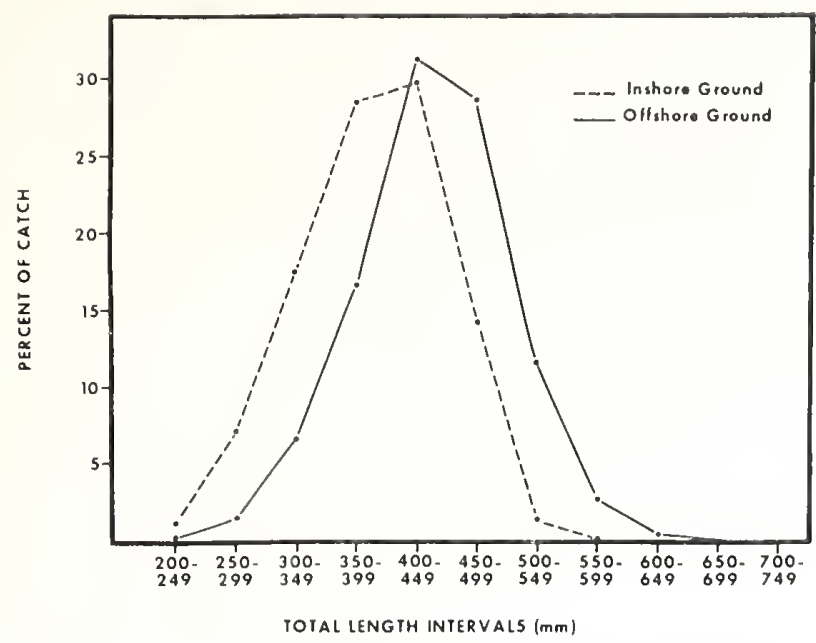

Figure 9.-Length-frequency distribution for 13,120 red porgy collected on inshore and offshore fishing grounds off the Carolinas (from Manooch 1975).

II -8.5, III -17.2, IV $-22.2, \mathrm{~V}-11.6, \mathrm{VI}-9.4, \mathrm{VII}-11.9$, VIII-8.2, IX-4.7, X-1.9, and $>\mathrm{X}-3.9$.

\subsection{Size composition}

Red porgy caught by hook and line off the Carolinas from 1972 to 1974 ranged from 212 to $741 \mathrm{~mm}$ (8.3 to 29.2 in) TL. Over half ( $56.3 \%)$ of the fish landed were between 400 and $499 \mathrm{~mm}$ (15.7 and $19.6 \mathrm{in}$ ) TL and averaged 425.4 $\mathrm{mm}$ (16.7 in) (Fig. 7). The length-weight relationship predicts an average weight of $1.0 \mathrm{~kg}(2.25 \mathrm{lb})$ for a 425 $\mathrm{mm}$ fish.

Size of red porgy varied only slightly between years. Average fish size was largest in $1973 ; 439.5 \mathrm{~mm}$ (17.3 in) TL and $1.1 \mathrm{~kg}$ (2.48 lb). Average size for the other years was very similar. The largest red porgy sampled was 741 $\mathrm{mm}$ (29.2 in) and $5.1 \mathrm{~kg}(11.2 \mathrm{lb})$ landed in South Carolina in 1974.

Mean sizes were again similar by area. Fish averaged slightly larger in the Cape Romain district: $426.7 \mathrm{~mm}$ (16.8 in) and $1.0 \mathrm{~kg}(2.26 \mathrm{lb})$ compared with $425.0 \mathrm{~mm}$ (16.7 in) $(0.8 \mathrm{~kg}(1.83 \mathrm{lb}))$ and $421.8 \mathrm{~mm}$ (16.7 in) $(1.0 \mathrm{~kg}$ (2.19 lb)) for Cape Lookout and Cape Fear districts, respectively. A different length-weight relationship was used for each area resulting in different mean weights per length of fish. A larger percentage of smaller fish $(<350$ $\mathrm{mm}$ ) were caught in the Cape Fear district, and relatively more individuals greater than $600 \mathrm{~mm}$ (23.6 in) were landed in South Carolina. One explanation of the occurrence of smaller fish in the Cape Fear vicinity is that a greater fraction of the effort is inshore, where smaller hooks are used and smaller fish are found.

A more pronounced difference in size is revealed by stratifying data according to inshore and offshore fishing grounds. Inshore fish were consistently smaller for each year compared with red porgy caught on the offshore grounds (Fig. 9). Mean size for inshore fish for all years was $387.6 \mathrm{~mm}$ (15.2 in) and $0.78 \mathrm{~kg}(1.72 \mathrm{lb})$ compared with $436.6 \mathrm{~mm}$ (17.2 in) and $1.1 \mathrm{~kg}$ (2.43 lb) offshore. Ap- proximately $69 \%$ of the fish collected in shallower water ranged from 325 to $449 \mathrm{~mm}$ (12.8-17.7 in), and $68 \%$ of the offshore individuals ranged from 400 to $524 \mathrm{~mm}$ (15.720.6 in) TL.

Pagrus pagrus exploited commercially off South America are generally smaller than those sampled from the Carolina recreational fishery. Fish from Argentina ranged from 100 to $540 \mathrm{~mm}$ TL, and most were between 260 and $380 \mathrm{~mm}$ (Cotrina and Cousseau see footnote 3 ). Cordeiro and Miyares (pers. commun.) reported that specimens caught commercially by hook and line off Brazil are generally 320 to $380 \mathrm{~mm}$ in length.

\subsection{Abundance and density}

Data on standing crop or biomass per unit area for red porgy are limited. While no information is available from North America or the eastern Atlantic, Yesaki (pers. commun.) gives estimates between 78,000 to $104,000 \mathrm{t}$ in 1973 and 10,000 to $55,000 t$ in 1974 during December off the southern coast of Brazil.

The NMFS has conducted surveys which report catch and catch per unit effort (CPUE) for $P$. pagrus off the Carolinas. The following discussion is from Manooch (1975): "A recreational fishery exists for the species throughout much of its U.S. range. Most of the effort is from headboat ${ }^{5}$ anglers although private and charter vessels also land Pagrus. Unfortunately, catch and effort statistics are lacking except for North Carolina and South Carolina, where in 1972 the National Marine Fisheries Service initiated studies of offshore demersal stocks. In 1972, 1973, and 1974 over 700,000 fish weighing 771 metric tons were caught by North Carolina and South Carolina anglers (Sekavec and Huntsman 1972; Huntsman 1976). The species contributed $50 \%$ by number, and $44.6 \%$ of the weight of all offshore demersal species harvested by the fishery excluding black sea bass, Centropristis striata."

Red porgy are also landed commercially; however, the species is generally combined with two other genera of porgy, Stenotomus and Calamus, under the heading "scup" or "porgy" (Anonymous 1971). The species probably represents only a small percentage of this category, but would be impossible to separate by reviewing these catch records.

Catch and effort data for the years 1972 to 1974 are presented in Table 2 stratified by inshore and offshore fishing. For the $3 \mathrm{yr}$ surveyed, 705,372 red porgy weighing $786.95 \mathrm{t}$ were caught during 193,564 angler days of fishing. This results in a mean catch of 3.64 red porgy and $4.07 \mathrm{~kg}$ per angler day.

In 1972, 48,991 angler days were expended to catch 215,958 red porgy which weighed $235.3 \mathrm{t}$. The average fisherman offshore caught approximately 6 fish $(7.26 \mathrm{~kg})$ per angler compared with $2.5(2.27 \mathrm{~kg})$ fish for anglers fishing inshore.

\footnotetext{
${ }^{5}$ Headboats are boats where anglers pay for a day's fishing on a per person basis.
} 
Table 2.-Catch and effort data for red porgy stratified by trip type and year, 1972-74 (from Manooch 1975).

\begin{tabular}{llrrrrr}
\hline lear & Trip type & $\begin{array}{c}\text { Angler } \\
\text { days }\end{array}$ & $\begin{array}{c}\text { Number } \\
\text { caught }\end{array}$ & $\begin{array}{c}\text { Total weight } \\
\text { (metric tons) }\end{array}$ & No./angler & Wt./angler \\
\hline 1972 & Offshore & 25,082 & 156,463 & 185 & 6.24 & 16.23 \\
\multirow{2}{*}{ Subtotal } & Inshore & 23,909 & 59,495 & 51 & 2.49 & 4.68 \\
1973 & Offshore & 48,991 & 215,958 & 235 & 4.41 & 10.59 \\
\multirow{2}{*}{ Subtotal } & Inshore & 16,731 & 227,018 & 280 & 5.31 & 14.45 \\
1974 & & 58,966 & 291,429 & 333 & 4.94 & 7.20 \\
& Offshore & 30.867 & 117,828 & 142 & 3.82 & 12.45 \\
Subtotal & Inshore & 54,740 & 80,157 & 77 & 1.46 & 3.09 \\
Totals & & 85,607 & 197,985 & 219 & 2.31 & 5.64 \\
\hline
\end{tabular}

Fishing was slightly better in 1973 . Approximately 59,000 angler days resulted in a catch of 291,429 red porgy which totaled $333.0 \mathrm{t}$. The average catch per angler day was 4.9 fish weighing $5.65 \mathrm{~kg}$. Again, as in 1972, offshore angling produced a higher CPUE than did inshore fishing: 5.31 fish $(6.35 \mathrm{~kg})$ per angler day compared with $4.00(3.18 \mathrm{~kg})$.

Catch per angler day dropped rather drastically in 1974. Approximately 85,600 angler days resulted in a catch of 197,985 fish which weighed $218.6 \mathrm{t}$. The average catch of 2.31 fish and $2.55 \mathrm{~kg}$ per angler day was the lowest of the $3 \mathrm{yr}$ surveyed. As with the preceeding years, fishing was better offshore, 3.82 red porgy per angler day, compared with inshore, 1.46 per angler day. One explanation for the increase in effort and a factor which reduced CPUE is that in 1974, nine additional inshore boats in South Carolina were included in the survey. Not only did these boats increase the effort by 39,248 angler days. but they also fished very shallow areas which are typically black sea bass fishing grounds. Excluding these boats, 160,254 red porgy were harvested by 46,359 angler days; a catch rate of 3.46 fish per angler day.

Catch per unit effort for red porgy increased southward. For all years combined, fishing grounds in the Cape Fear district produced the highest catch per angler day, 4.73 fish and $5.01 \mathrm{~kg}$. Fishing effort was greatest in the Cape Romain district and was actually composed of $47 \%$ of the total angler days for all areas combined. Catch per unit effort was also relatively high in South Carolina: 4.14 red porgy and $4.60 \mathrm{~kg}$ per angler day. The South Carolina catch per angler day is 6.54 fish and $7.40 \mathrm{~kg}$ per angler day if the 1974 inshore boats are excluded. Fishing at Cape Lookout and Cape Hatteras, N.C., was less productive. Only 1.91 fish per angler day were caught in the Cape Lookout district and 2.13 at Cape Hatteras.

Fishing offshore was almost always more rewarding than fishing inshore. Catch per unit effort was better inshore at Cape Hatteras, but there was a small number of angler days fished.

The highest catch rate obtained was 9.08 red porgy and $10.31 \mathrm{~kg}$ per angler day, offshore in the Cape Romain area in 1972; and the lowest was 0.66 fish and $0.55 \mathrm{~kg}$ per angler day for 1974 anglers, inshore at Cape Lookout.

Catch per unit effort not only varied with year and geographical location, but also between seasons.
Seasonal differences were very inconsistent. For all years and areas combined, spring revealed the highest CPUE, 3.90 red porgy and $4.17 \mathrm{~kg}$ per angler day. However, inspection of the combined data reveals little difference in the catch rates: spring, 3.90 porgy and $4.17 \mathrm{~kg}$ per angler day; June, 3.84 and $4.07 \mathrm{~kg}$; July', 3.50 and $4.09 \mathrm{~kg}$; August, 3.33 and $3.95 \mathrm{~kg}$; and fall, 3.81 fish and $4.13 \mathrm{~kg}$.

Inspection of these data by year indicates the highest CPUE in the fall for 1972 and 1974 and in the spring for 1973.

Looking at each stratum independently, the highest CPUE occurred offshore in June 1972, 7.47 fish and 8.41 $\mathrm{kg}$ per angler day. Unmeasured variables such as weather, currents, and angler quality undoubtedly have pronounced effects on catch per angler day.

\subsection{Mortality and morbidity}

Total annual mortality rates were calculated for red porgy off North Carolina and South Carolina (Manooch and Huntsman 1977). Age composition of 1,777 red porgy obtained from 1972 to 1974 from the North Carolina and South Carolina headboat fishery was derived by scale reading. The fish were grouped into $25-\mathrm{mm}$ size intervals and the percentage (probability value $z$ ) for each age (I-XII) was identified for each size interval. Probability values for each age and size interval could then be applied to the length-frequency data derived from 13,120 fish sampled from the sport fishery for the years 1972 to 1974. These data were then stratified by year and area of collection.

Mean total annual mortality estimates for red porgy in North Carolina and South Carolina ranged from 32 to $55 \%$ (Table 3). Little difference was noted in values obtained by the various methods, although the authors considered the regression method to be the best estimator since it utilized geometric rather than arithmetic means. The slope of the descending right limb of the catch curve equals the instantaneous rate of mortality and can be easily converted to total annual mortality (Ricker 1975).

By year, the highest mean annual mortality rate for red porgy was $49 \%$ in 1972 , and the lowest mortality was $43 \%$ in 1973 . Thus, $43 \%$ of the red porgy of ages V and 
Table 3.-Total annual mortality estimates for red porgy from North Carolina and South Carolina, 1972-74 (from Manooch 1975).

\begin{tabular}{|c|c|c|c|c|c|c|c|c|c|c|}
\hline \multirow[b]{2}{*}{ Year } & \multirow[b]{2}{*}{ Area } & \multicolumn{4}{|c|}{ Method } & \multirow[b]{2}{*}{ Regression } & \multirow[b]{2}{*}{$\begin{array}{c}\text { Sample } \\
\text { size } \\
\text { (V-oldest) }\end{array}$} & \multirow[b]{2}{*}{$\begin{array}{l}\text { Number } \\
\text { of age } \\
\text { classes }\end{array}$} & \multirow[b]{2}{*}{$\begin{array}{c}\text { Mean } \\
\text { mortality }\end{array}$} & \multirow[b]{2}{*}{$\begin{array}{c}\text { Mean } \\
\text { survival }\end{array}$} \\
\hline & & Ricker & $\begin{array}{c}\text { Robson } \\
\text { and } \\
\text { Chapman }\end{array}$ & Heinke & $\begin{array}{c}\text { Rounsefell } \\
\text { and } \\
\text { Everhart }\end{array}$ & & & & & \\
\hline $1972-74$ & Combined & 0.43 & 0.44 & 0.43 & 0.47 & 0.44 & 9,066 & 9 & 0.44 & 0.55 \\
\hline \multirow[t]{4}{*}{1972} & 1 & 0.32 & 0.36 & 0.32 & & 0.29 & 474 & 7 & 0.32 & 0.68 \\
\hline & 2 & 0.54 & 0.55 & 0.54 & & 0.55 & 779 & 7 & 0.55 & 0.45 \\
\hline & 3 & 0.48 & 0.52 & 0.48 & & 0.55 & 1,621 & 8 & 0.52 & 0.48 \\
\hline & Combined & 0.47 & 0.49 & 0.47 & & 0.52 & 2,883 & 9 & 0.49 & 0.51 \\
\hline \multirow[t]{4}{*}{1973} & 1 & 0.38 & 0.42 & 0.38 & & 0.39 & 833 & 7 & 0.40 & 0.60 \\
\hline & 2 & 0.35 & 0.38 & 0.35 & & 0.37 & 1,299 & 8 & 0.37 & 0.63 \\
\hline & 3 & 0.44 & 0.46 & 0.44 & & 0.43 & 1,888 & 8 & 0.44 & 0.56 \\
\hline & Combined & 0.40 & 0.42 & 0.40 & & 0.47 & 4,044 & 9 & 0.43 & 0.57 \\
\hline \multirow[t]{4}{*}{1974} & 1 & 0.35 & 0.36 & 0.35 & & 0.40 & 259 & 8 & 0.37 & 0.63 \\
\hline & 2 & 0.48 & 0.47 & 0.48 & & 0.43 & 600 & 7 & 0.46 & 0.54 \\
\hline & 3 & 0.44 & 0.44 & 0.44 & & 0.42 & 1,218 & 9 & 0.43 & 0.57 \\
\hline & Combined & 0.44 & 0.43 & 0.44 & & 0.44 & 2,077 & 9 & 0.44 & 0.56 \\
\hline
\end{tabular}

older were expected to die that year attributable either to harvest or natural causes.

Geographically, Cape Lookout generally had the lowest annual mortality for the $3 \mathrm{yr}: 32 \%, 40 \%$, and $37 \%$. Overall, Cape Fear had the highest rates of total annual mortality: $55 \%, 37 \%$, and $46 \%$.

4.6 The population in the community and the ecosystem

Although the habitats are fairly similar off northwest Africa, South America, and the southeastern United States, with respect to depth range, temperature, and substrate, species of fish associated with the red porgy vary. Wozinak (1967) listed the following species of sparids commonly found with $P$. pagrus off northwest Africa: Dentex filosus, $D$. canariensis, $D$. macrophthalmus, D. maroccanus, Chrysophrys aurata, Pagrus ehrenbergi, $P$. auriga, Pagellus canariensis, $P$. mormyrus, $P$. acarne, $P$. bogaraveo, Sargus vulgaris, $S$. bellotti, Charax puntazzo, Box boops, and Cantharus cantharus. Klimaj (1970) also listed species of fish trawled with $P$. pagrus. His list of sparids is very similar to that above, and also includes other families and species (Table 4).

Austin (see footnote 4) mentioned the red porgy as the most commonly caught species of fish on the Florida Middle Ground, a reef located off Tampa, in the Gulf of Mexico. Physical characteristics of the area are referred to in section 2.1. An ecological condition noted by Austin was: dense carpet of brown algae during summer, disappearing in fall and winter. The only winter benthic algae observed was heavily grazed colonies of Caulerpa pelatata. During summer when they are abundant, herbivorous crabs such as Mithrax pluvacantha are major foods of demersal fish. Species of fishes found collected with red porgy are listed in Table 5 .

Manooch (1975) identified concentrations of red porgy at two major depth regimes off North Carolina and South Carolina (section 2.1). Species of carnivorous fishes caught with $P$. pagrus revealed two different communities. Along the southern coast of Brazil (Espirito
Santo) large schools of Pagrus pagrus are found associated with dence growths of the algae Laminaria (Cordeiro and Miyares, pers. commun.). The species generally concentrates along mussel beds at a depth of approximately $30 \mathrm{~m}$ off Argentina (M. Haimovici, pers. commun., Fundacão Universidade do Rio Grande).

\section{FISHING}

Since the red porgy is so widely distributed and is landed by fisheries of nations with diverse cultures in the Americas, Africa, and Europe, fishing techniques vary from one area to another. Fisheries of the southeastern United States, northwest Africa, and South America have been described and will be discussed under the headings which follow.

\subsection{Fishing Equipment}

\subsection{Gear}

Bottom trawls, traps, and hook-line are used to capture $P$. pagrus. Off the Carolinas red porgy are taken almost exclusively by hook and line by both :ecreational and commercial fishermen. Huntsman (1976) described gear used aboard headboats. Tackle used on the boats is heavy and sturdy enough to resist the abuse of inexperienced anglers, and to land large fish. Fish are caught using $6 / 0$ to $9 / 0$ reels, either powered manually or electrically. Rods are generally constructed of fiberglass with the rod blank extending through the handle. Lines are 80 - to 120 -lb monofilament. Baits (squid and cut fish) are fished directly on the bottom using rigs constructed of $80-\mathrm{lb}$ monofilament line with two $4 / 0$ to $7 / 0$ hooks. Sinkers vary from 8 to $28 \mathrm{oz}$ depending on current velocity or depth. Heavy sinkers seem to increase effectiveness of bait presentation during rough seas or when currents sweep lighter weights from the bottom. "Snapper reels," which also utilize hook and line, are commonly used on snapper boats of the southeastern and gulf coasts of 
Table 4.-Species of fish trawled with Pagrus pagrus off Mauritania and Senegal, by depth and month(s) (from Klimaj 1970).

\begin{tabular}{|c|c|c|c|}
\hline \multirow[b]{2}{*}{ Family:Species } & \multicolumn{3}{|c|}{ Depth occurred with Pagrus pagrus } \\
\hline & $\begin{array}{c}28 \text { Mar.- } \\
18 \mathrm{Apr} . \\
(110-135 \mathrm{~m})\end{array}$ & $\begin{array}{l}11-30 \mathrm{May} \\
(40-150 \mathrm{~m}) \\
\end{array}$ & $\begin{array}{c}20 \text { June- } \\
10 \text { July } \\
(18-120 \mathrm{~m})\end{array}$ \\
\hline \multicolumn{4}{|l|}{ Pomatomidae } \\
\hline Pomatomus saltatrix & $110-135$ & $40-150$ & $18-120$ \\
\hline \multicolumn{4}{|l|}{ Carangidae } \\
\hline Trachurus trachurus & $110-135$ & $40-150$ & $18-120$ \\
\hline Trachurus picturatus & $110-135$ & $50-150$ & $18-120$ \\
\hline Decapturus punctatus & $110-135$ & $40-150$ & $65-120$ \\
\hline Decapturus ronchus & $110-135$ & $40-150$ & $18-120$ \\
\hline Selar crumenophthalmus & $110-135$ & $50-150$ & $65-120$ \\
\hline Vomer setipinnis & $110-135$ & $40-125$ & $65-120$ \\
\hline Lichia vadigo & - & $40-150$ & $18-120$ \\
\hline \multicolumn{4}{|l|}{ Sparidae } \\
\hline Pagrus ehrenbergi & $110-135$ & $40-150$ & $18-120$ \\
\hline Dentex macrophthalmus & $110-135$ & $50-150$ & $65-120$ \\
\hline Dentex filosus & $110-135$ & $40-150$ & $65-120$ \\
\hline Pagellus centrodontus & $110-135$ & - & - \\
\hline Pagellus erythrinus & - & $50-150$ & $65-120$ \\
\hline Pagellus acarne & $110-135$ & $40-150$ & $65-120$ \\
\hline Cantharus lineatus & $120-135$ & - & - \\
\hline Sparus aurata & $110-135$ & $40-150$ & $95-120$ \\
\hline Sarpa salpa & - & $70-150$ & $65-120$ \\
\hline Diplodus annularis & $110-135$ & 40. 80 & - \\
\hline Dentex canariensis & - & $50-150$ & $65-120$ \\
\hline Boops boops & - & $40-150$ & $65-120$ \\
\hline Pagellus bogaraveo & - & $40-150$ & $65-120$ \\
\hline Diplodus sargus & - & $70-80$ & $65-120$ \\
\hline \multicolumn{4}{|l|}{ Sciaenidae } \\
\hline Johnius hololepidotus & $120-135$ & - & $65-120$ \\
\hline Sciaena cirrosa & $120-135$ & 40. 45 & $65-120$ \\
\hline Sciaena ronchus & - & $50-150$ & - \\
\hline \multicolumn{4}{|l|}{ Serranidae } \\
\hline Serranus aeneus & $120-135$ & - & $65-120$ \\
\hline Serranus alexandrinus & $110-135$ & - & - \\
\hline \multicolumn{4}{|l|}{ Scombridae } \\
\hline Scomber japonicus & $110-135$ & $40-150$ & 18- 75 \\
\hline Orcynopsis unicolor & - & - & 18- 24 \\
\hline \multicolumn{4}{|l|}{ Lutjanidae } \\
\hline Brachydeuterus auritus & $120-135$ & $70-150$ & $65-120$ \\
\hline Parapristipoma mediterraneum & - & - & $18-120$ \\
\hline \multicolumn{4}{|l|}{ Clupeidae } \\
\hline Sardinella aurita & $110-135$ & $60-125$ & 18- 75 \\
\hline \multicolumn{4}{|l|}{ Zeidae } \\
\hline Zeus faber & $110-135$ & - & - \\
\hline \multicolumn{4}{|l|}{ Gadidae } \\
\hline Merluccius merluccius & $110-135$ & $50-80$ & $65-120$ \\
\hline \multicolumn{4}{|l|}{ Trichiuridae } \\
\hline Trichiurus lepturus & $110-135$ & $40-150$ & $18-110$ \\
\hline \multicolumn{4}{|l|}{ Sphyraenidae } \\
\hline Sphyraena barracuda & - & $50-105$ & 18- 75 \\
\hline
\end{tabular}

North America. They are usually electrically or hydraulically operated.

Apparently hand lines as well as traps have been used for many years to catch red porgy and other sparids off northwest Africa. Murray and Hjort (1912) described these techniques from the Canary Islands, and the author observed almost identical gear in 1974. Brandt (1970) referred to fishing equipment used off northwest Africa for many groups of fish including sparids: ". . generally speaking the traditional fisheries in the area under discussion use lines (hand-lines and longlines), gill nets (set nets and drift nets) and beach seines.
Traps (for fish and crustaceans), cast nets and also small surrounding nets are also well known." Trawls (bottom trawls, one-boat and two-boat systems) are also used. Detailed descriptions and illustrations of various bottom trawls as used by the Soviet Union and Poland are provided by Savrasov (1970) and Czajka and Burawa (1970), respectively. Traps, trawls, and handlines are used to capture $P$. pagrus off the east coast of South America. There are two principal Argentine fleets (Cotrina and Cousseau see footnote 3). Small trap boats fish relatively close to shore in shallow water and the catch is sold locally. Cordini (1962) provided a description of the fish traps or nasas. Larger vessels trawl for Pagrus in deeper waters and the fish are generally frozen and exported. Cordeiro and Miyares (pers. commun.) stated that they are collected off the southern coast of Brazil by handline. Commercial fishermen use lines that have 12 hooks.

\subsection{Boats}

Huntsman (1976) described the three basic qualities of headboats used off the southeastern United States: 1) ample passenger capacity; 2) sufficient speed to make the long trip offshore acceptable to anglers; and 3) loran and depth recording instruments to locate fish and suitable bottom topography. Passenger capacity of both inshore and offshore boats vary from 30 to 75 anglers. Speed is most essential to offshore boats and they may attain speeds up to $34.5 \mathrm{kn}$, although $23 \mathrm{kn}$ is about average. Boats vary in length from 18 to $34 \mathrm{~m}$.

There is a great diversity in fishing vessels used off northwest Africa. A traditional fishery with pirogues (canoes) with various modifications including sails, and row boats exist simultaneously with national and foreign fleets of big factory and freezer trawlers. Fishing vessels, then, range in size from small rowing boats to big stern trawlers and factory ships (Brandt 1970). Brandt (1970) reported that the greatest influence on fish stocks (including sparids) off the West African Shelf are the highly developed trawlers of foreign nations, especially freezerstern trawlers of Western, Southern, and Eastern Europe as well as the Far East. Russian and Polish trawling vessels are discussed in detail by Savrasov (1970) and Czakja and Burawa (1970).

In addition to these rather large fishing vessels, there exists off northwest Africa a fleet of small line and trap boats mainly of Spanish and Mauritanian origin. South American vessels were briefly mentioned in the previous section.

\subsection{Fishing areas}

Fishing grounds off North Carolina and South Carolina are identified by Manooch (1975) and are fairly representative of the entire southeast U.S. coast: "The outer Continental Shelf of the Carolinas provides two types of habitat which serve as fishing grounds for red porgy. The most spectacular of these is the shelf break zone (Struhsaker 1969) where the ocean floor slopes 
Table 5.- List of fishes observed on the Florida Middle Ground, in addition to red porgy (from Austln see text footnote 4).

\begin{tabular}{|c|c|c|c|c|c|}
\hline Family & Species & Common name & Family & Species & Common name \\
\hline \multirow[t]{3}{*}{ Caracharhinidae } & Carcharhinus falciformis & Silky shark & & Decapterus sp. & Scad \\
\hline & Carcharhinus leucas & Bull shark & & Naucrates ductor & Pilotfish \\
\hline & Galeocerdo cuvieri & Tiger Shark & & Seriola dumerili & Greater amberjack \\
\hline Clupeidae & Etrumeus teres & Round herring & & Trachurus lathami & Rough scad \\
\hline Engraulidae & Anchoviella perfasciata & Flat anchovy & Coryphaenidae & Coryphaena hippurus & Dolphin \\
\hline Synodontidae & Synodus intermedius & Sand diver & Pomadasyidae & Haemulon aurolineatum & Tomtate \\
\hline Muraenidae & Gymnothorax moringa & Spotted moray & & Haemulon plumieri & White grunt \\
\hline \multirow[t]{3}{*}{ Ophichthidae } & Ahlia egmontis & Key worm eel & Sciaenidae & Equetus umbrosus & Cubbyu \\
\hline & Myrophis punctatus & Speckled worm eel & Mullidae & Mullus auratus & Red goatfish \\
\hline & Ophichthus gomesi & Shrimp eel & Sparidae & Calamus nodosus & Knobbed porgy \\
\hline Belonidae & Tylosurus crocodilus & Houndfish & Ephippidae & Chaetodipterus faber & Atlantic spadefish \\
\hline \multirow[t]{5}{*}{ Exocoetidae } & Euleptorhamphus velox & Flying halfbeak & Chaetodontidae & Chaetodon c.f. ocellatus & Spotfin butterflyfish \\
\hline & Hemiramphus brasiliensis & Ballyhoo & & Pomacanthus arcuatus & Gray angelfish \\
\hline & Cypselurus heterurus & Atlantic flyingfish & & Holacanthus bermudensis & Blue angelfish \\
\hline & Parexocoetus brachypterus & Sailfin flyingfish & Pomacentridae & Chromis c.f. scotti & Purple reeffish \\
\hline & Hirundichthys rondeleti & Blackwing flyingfish & & Pomacentrus c.f. variabilis & Cocoa damselfish \\
\hline Bregmacerotidae & Bregmaceros atlanticus & Antenna codlet & Labridae & Bodianus rufus & Spanish hogfish \\
\hline Holocentridae & Holocentrus ascensionis & Squirrelfish & & Halichoeres bivittatus & Slippery dick \\
\hline \multirow[t]{8}{*}{ Serranidae } & Centropristis ocyurus & Bank sea bass & & Lachnolaimus maximus & Hogfish \\
\hline & Diplectrum formosum & Sand perch & & Thalassoma bifasciatum & Bluehead \\
\hline & Epinephelus adscensionis & Rock hind & Scaridae & Sparisoma sp. & Parrotfish \\
\hline & Epinephelus guttatus & Red hind & Acanthuridae & Acanthurus chirurgus & Doctorfish \\
\hline & Epinephelus morio & Red grouper & Gempylidae & Gempylus serpens & Snake mackerel \\
\hline & Mycteroperca microlepis & $\mathrm{Gag}$ & Scombridae & Scomberomorus maculatus & Spanish mackerel \\
\hline & Mycteropercaphenax & Scamp & Gobiidae & Gobiosoma oceanops & Neon goby \\
\hline & Petrometopon cruentatum & Graysby & Scorpaenidae & Scorpaena plumieri & Spotted scorpionfish \\
\hline \multirow[t]{5}{*}{ Lutjanidae } & Lutjanus campechanus & Red snapper & Sphyraenidae & Sphyraena barracuda & Great barracuda \\
\hline & Lutjanus griseus & Gray snapper & Mugilidae & Mugil cephalus & Striped mullet \\
\hline & Lutjanus synagris & Lane snapper & Bothidae & Syacium micrurum & Channel flounder \\
\hline & Ocyurus chrysurus & Yellowtail snapper & Soleidae & Gymnachirus melas & Naked sole \\
\hline & Rhomboplites aurorubens & Vermilion snapper & Cynoglossidae & Symphurus sp. & Tonguefish \\
\hline Priacanthidae & Pristigenys alta & Short bigeye & Echeneidae & Echeneis naucrates & Sharksucker \\
\hline Apogonidae & Apogon pseudomaculatus & Twospot cardinalfish & Balistidae & Balistes capriscus & Gray triggerfish \\
\hline Rachycentridae & Rachycentron canadum & Cobia & & Monacanthus setifer & Pygmy filefish \\
\hline Carangidae & Caranx ruber & Bar jack & Batrachoididae & Opsanus pardus & Leopard toadfish \\
\hline
\end{tabular}

abruptly from the Continental Shelf to the Continental Slope. This break zone occupies an area from 30 to 100 fathoms and is characterized by very irregular topography of jagged peaks, precipitous cliffs, and rocky ledges. Less spectacular, but equally productive are the 'live bottom' areas (Struhsaker 1969) of the Continental Shelf shoreward of the shelf break area. Scattered over this submarine plain are numerous shipwrecks, rock outcroppings, and coral patches (Huntsman and Macintyre 1971) which provide ideal habitat for red porgy. Boats which fish over the latter are referred to as 'inshore' boats and those that fish the shelf break are referred to as 'offshore' (Fig. 10) vessels."

Large quantities of $P$. pagrus and other sparids are taken commercially off northwest Africa. The following description of the major fishing area from Morocco to Senegal was taken from Brandt (1970). The area under discussion (lat. $36^{\circ} \mathrm{N}$ to $15^{\circ} \mathrm{N}$ ) corresponds to the old French and Portuguese fishing areas $\mathrm{Xa}, \mathrm{Xb}$ including Madeira Islands, XIa with the Canary Islands, XIb, and the northern part of XIIa, as well as Portuguese fishing area XIIc with the Cape Verde Islands to long. $28^{\circ} \mathrm{W}$. This area also corresponds to the Italian fishing areas $14 \mathrm{a}, 14 \mathrm{~b}$ with Madeira Islands, $14 \mathrm{c}$ with Canary Islands, and 14f. Morocco, Ifni, Rio de Oro (Spanish Sahara), Mauritania, and the northern part of western Senegal are the most important fishing areas. Coral reefs hinder bot- tom trawling in some areas especially the northernmost coast of Morocco to Cape Juby; this area is mainly for pelagic fishing. Bottom trawling is more prevelant off

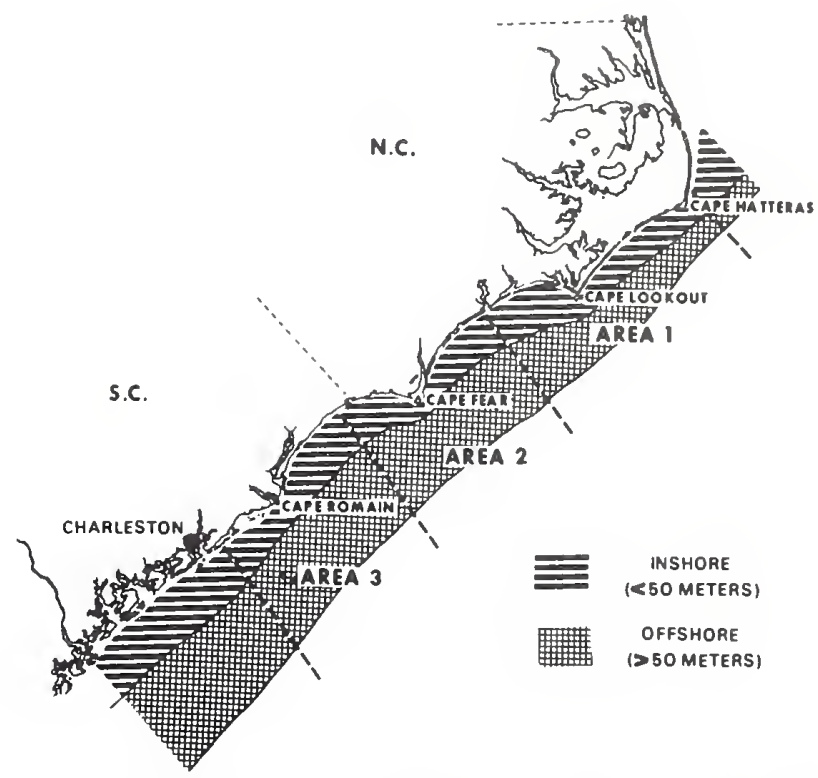

Figure 10.-Inshore and offshore fishing grounds off North Carolina and South Carolina (from Manooch 1975). 


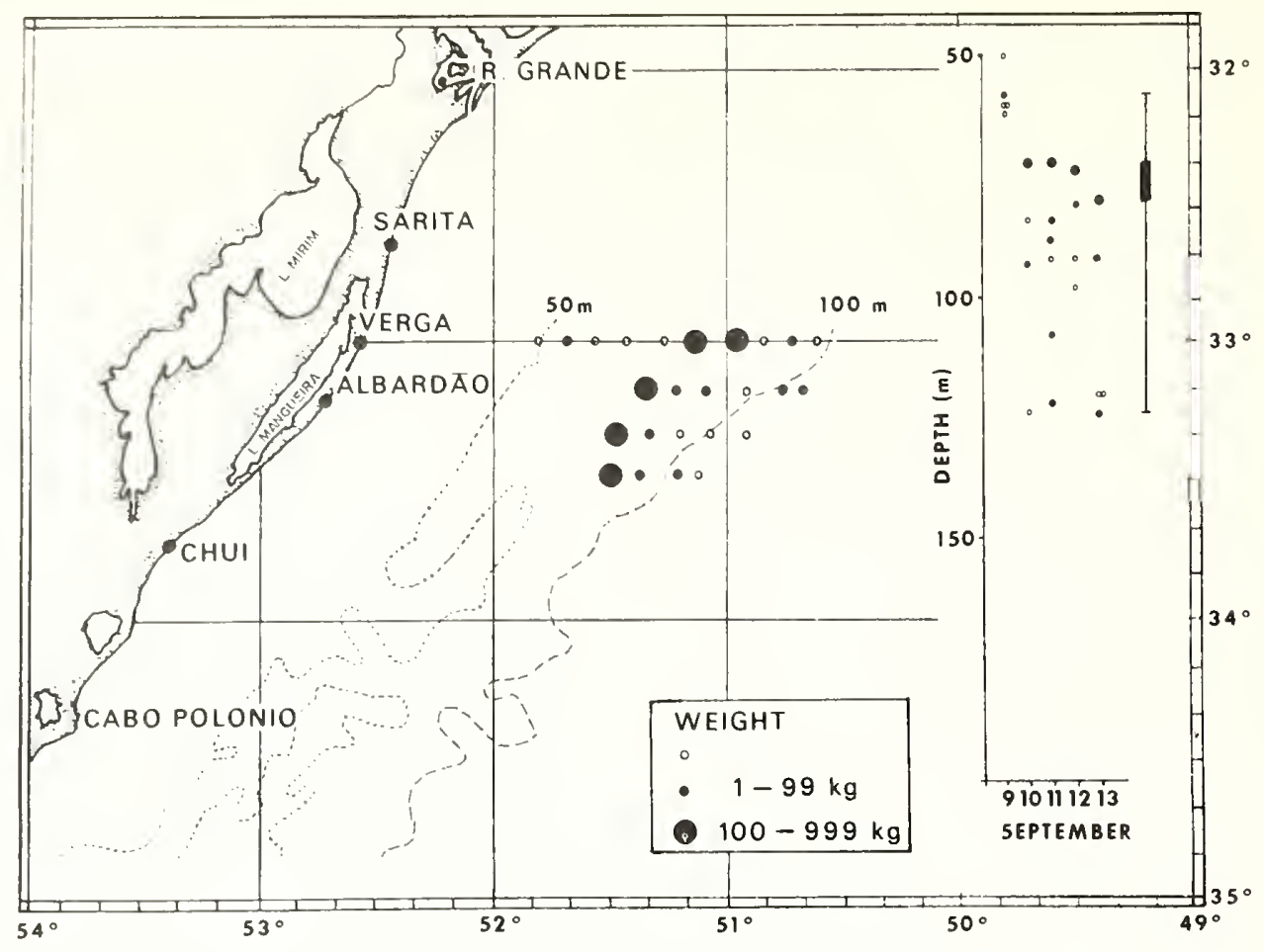

Figure 11.-Fishing grounds off Brazil (from Yesaki and Barcellos 1974).

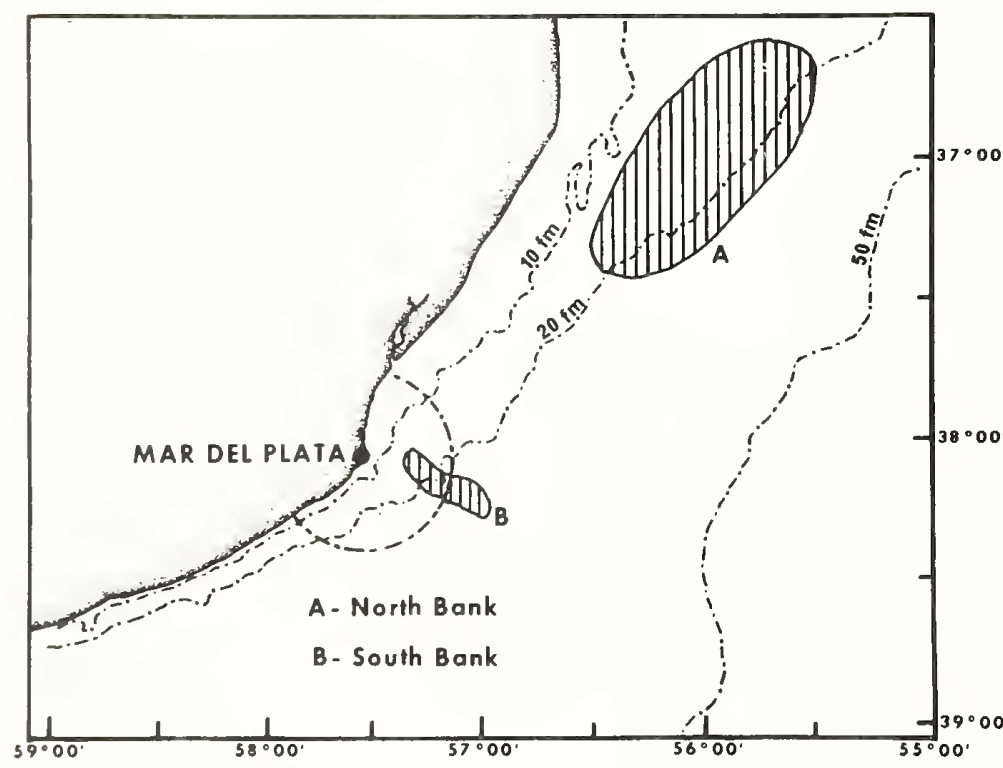

Figure 12.-Major Argentine fishing areas (from Cotrina and Cousseau, see text footnote 3 ).

the coast of Rio de Oro (Spanish Sahara). This includes Arguin Bank off the northern coast of Mauritania south of Port Etienne about $18 \mathrm{mi}$ off the coast. The Baie du Levrier is the nearest part of the bank from Port Etienne and one of the few sheltered areas of the coast protected by Cape Blanco. The shelf here is about $80 \mathrm{mi}$ wide. The whole area from Cape Juby and the Arguin Bank is considered suitable for bottom trawling. Of the three groups of islands (Madeira, Canary, and Cape Verde) included in this large geographical area, only the Canary Islands have fisheries which are closely associated with the northwest coast of Africa. Fishing grounds off South America are illustrated by Yesaki and Barcellos (1974) in Figure 11 and Cotrina and Cousseau (see footnote 3 ) in Figure 12.

\subsection{Fishing seasons}

Fishing seasons for red porgy off the southeastern United States are not regulated by law and probably not by differences in seasonal availability, but rather by weather and economic factors. Landings are not reported 
on a monthly or seasonal basis for most of the fishing areas in the Atlantic. Manooch (1975) found little difference in CPUE for $P$. pagrus caught by hook and line off the Carolinas. Cotrina and Cousseau (see footnote 3) reported higher trawl catches in summer (DecemberMarch) off Argentina, but that the species is taken throughout the year by trap fishermen.

\subsection{Fishing operations and results}

The Beaufort Laboratory, NMFS, has collected catch and effort data from North Carolina and South Carolina headboats since 1972. These data are the only species specific catch information available for red porgy landed

Table 6.- Catch of red porgy in thousands of metric tons caught off South America.'

\begin{tabular}{lrrrrr}
\hline & \multicolumn{4}{c}{ Country } & \\
\cline { 2 - 4 } Year & Argentina & Brazil & USSR & Venezuela & Totals \\
\hline 1938 & 0.1 & & & & 0.1 \\
1948 & 0.4 & & & & 0.4 \\
1958 & 1.6 & 0.7 & & & 2.3 \\
1959 & 1.7 & & & & 1.7 \\
1960 & 1.5 & & & & 1.5 \\
1961 & 1.3 & 0.7 & & & 2.0 \\
1962 & 1.4 & 0.7 & & & 2.1 \\
1963 & 1.7 & 1.1 & & & 2.8 \\
1964 & 2.1 & 1.2 & & & 3.3 \\
1965 & 2.1 & 3.1 & & & 5.2 \\
1966 & 3.1 & 3.4 & & & 6.5 \\
1967 & 2.5 & 5.4 & 17.6 & & 25.5 \\
1968 & 2.7 & 3.8 & 11.8 & 0.3 & 18.6 \\
1969 & 1.8 & 3.0 & & 0.2 & 5.0 \\
1970 & 2.1 & 3.2 & & & 5.3 \\
1971 & 1.9 & 3.2 & & & 5.1 \\
1972 & 1.6 & 4.7 & & & 6.3 \\
1973 & 3.6 & 4.7 & & & 8.3 \\
1974 & 1.4 & 4.7 & & & 6.1 \\
Totals & 34.6 & 43.6 & 29.4 & 0.5 & 108.1 \\
\hline
\end{tabular}

'Source: FAO Fishery Statistics Yearbooks 1938, 1948, and 1958-74. in the United States. Recreational catch data for other areas are nonexistent, and commercial landings are generally reported with several species of sparids combined. In the southeastern United States and Gulf of Mexico, $P$. pagrus is generally combined with two other genera of porgy, Stenotomus and Calamus, under the heading "scup or porgy" (Anonymous 1971). From northwest Africa $P$. pagrus is often reported under the heading "pagre" which includes several genera: Pagrus, Sparus, and Pagellus (Monteiro and Dias 1970).

\subsection{Effort and intensity}

Off the Carolinas red porgy are caught with serranids, pomadasyids, and lutjanids, using methods described in section 5.11. Effort was reported as catch per angler day: the number and/or kilograms of red porgy caught by one angler fishing 1 day (Sekavec and Huntsman 1972; Huntsman 1976; Manooch 1975). Catch and effort data for red porgy landed by recreational fishermen off North Carolina and South Carolina are presented in Table 2. Monteiro and Dias (1970) and Zei and Ansa-Emmim (1970) provided trawling effort by the Portuguese and Ghanaian trawlers, respectively, off northwest Africa, and Yesaki and Barcellos (1974) furnished CPUE for trawlers off Brazil.

\subsection{Catches}

As mentioned in section $5.4, P$. pagrus is generally combined with other sparids in landings reports. Some catch data are available in FAO Fishery Statistics Yearbooks 1938, 1948, and 1958-74. These catches, by country and fishing areas, are provided in Tables 6 and 7.

\section{ACKNOWLEDGMENTS}

We are indebted to the Sport Fishing Institute for providing financial assistance for a trip to the Canary Is-

Table 7.-Catches of red porgy in thousands of metric tons for years and areas where specific catch data are available.'

\begin{tabular}{|c|c|c|c|c|c|c|c|c|c|}
\hline \multirow{2}{*}{$\begin{array}{l}\text { Fishery areas } \\
\text { and country }\end{array}$} & \multicolumn{8}{|c|}{ Year } & \multirow[b]{2}{*}{ Total } \\
\hline & 1965 & 1966 & 1967 & 1968 & 1969 & 1970 & 1971 & 1972 & \\
\hline \multicolumn{10}{|l|}{ Atlantic, northeast } \\
\hline Spain & 0.6 & 0.3 & 0.4 & 0.3 & 0.6 & 0.5 & 0.5 & - & 3.2 \\
\hline Area subtotals & 0.6 & 0.3 & 0.4 & 0.3 & 0.6 & 0.5 & 0.5 & & 3.2 \\
\hline \multicolumn{10}{|c|}{ Atlantic, eastern central } \\
\hline Spain & 4.4 & 3.8 & 2.3 & 2.1 & 1.9 & 1.6 & 1.6 & - & 17.7 \\
\hline Area subtotals & 4.4 & 3.8 & 2.3 & 2.1 & 1.9 & 1.6 & 1.6 & & 17.7 \\
\hline \multicolumn{10}{|c|}{ Atlantic, southeast } \\
\hline Angola & 0.5 & 0.4 & 0.7 & 1.0 & 1.2 & 0.4 & 0.4 & 0.1 & 4.7 \\
\hline Area subtotals & 0.5 & 0.4 & 0.7 & 1.0 & 1.2 & 0.4 & 0.4 & 0.1 & 4.7 \\
\hline \multicolumn{10}{|c|}{ Mediterranean and Black Seas } \\
\hline \multicolumn{10}{|c|}{ Libyan Arab } \\
\hline Republic & 0.4 & 0.5 & 0.7 & 0.9 & 1.0 & 1.2 & 1.5 & 1.5 & 7.7 \\
\hline Spain & 0.0 & 0.1 & 0.1 & 0.1 & 0.1 & 0.1 & 0.1 & - & 0.6 \\
\hline Tunisia & - & - & - & - & - & 0.1 & 0.1 & 0.1 & 0.3 \\
\hline Turkey & 0.4 & 0.5 & 0.3 & 0.5 & 1.1 & 0.2 & 0.1 & 0.1 & 3.2 \\
\hline Area subtotals & 0.8 & 1.1 & 1.1 & 1.5 & 2.2 & 1.6 & 1.8 & 1.7 & 11.8 \\
\hline
\end{tabular}

'Source: FAO Fishery Statistics Yearbooks 1965-72. 
lands, and the Director, C. Garcia-Cabrera, and staff of the Laboratorio Oceanográfico de Canarias, Tenerife, Canary Islands, for technical assistance, laboratory space, and living accomodations while in the Canary Islands. We thank the following scientists who provided information on the species from their respective countries: V. H. Bertullo, Instituto de Investigaciones Pesqueras, Montevideo, Uruguay; H. P. Castello, Museo Argentino de Ciencias Naturales, Buenos Aires, Argentina; S. S. Cordeiro and A. Miyares, Programa de Pesquisa e Desenvolvimento Pequeiro do Brasil, Brasilia, Brasil; C. P. Cotrina, Instituto de Biologia Marine, Mar del Plata, Argentina; N. Ehrhardt, Instituto Nacional de Pesca, Montevideo, Uruguay; J. L. Guimaraes, Ministério da Agricultura/SUDEPE, Rio de Janerio, Brasil; M. Haimovici, Fundacão Universidade do Rio Grande, Base Oceanográfico Atlántica, Rio Grande, Brasil; N. A. Menezes, Museu de Zoologia da Universidade de São Paulo, São Paulo, Brasil; G. Vazzoler, Universidade de São Paulo, Instituto Oceanográfico, São Paulo, Brasil; and M. Yesaki, SUDEPE/PDP, Rio Grande, R. S. Brasil. We are also grateful to J. R. Montalva, Puerto Rico Nuclear Center, Mayaguez, P.R., for translating manuscripts and to John W. Reintjes and James E. Sykes, National Marine Fisheries Service, Beaufort, for reviewing the synopsis.

\section{LITERATURE CITED}

ANONYMOUS.

1971. Fisheries statistics of the United States, 1971. U.S. Dep. Commer., NOAA, Natl. Mar. Fish. Serv., Stat. Dig. 65, 424 p.

BEARDEN, C. M., and M. D. McKENZIE.

1971. An investigation of the offshore demersal fish resources of South Carolina. S.C. Wildl. Resour. Dep. Tech. Rep. No. 2, $19 \mathrm{p}$.

BEAUMARIAGE, D. S.

1969. Returns from the 1965 Schlitz tagging program including a cumulative analysis of previous results. Fla. Dep. Nat. Resour., Mar. Res. Lab., Tech. Ser. 59, 38 p.

BERTALANFFY, L. von.

1938. A quantitative theory of organic growth (inquiries on growth laws. II). Hum. Biol. 10:181-213.

BLOCH, M. E., and J. G. SCHNEIDER.

1801. Systema ichthyologiae iconibus CX illustratum, post obitum auctoris opus inchoatum absoluit. correxit, interpolavit. J. G. Schneider, Berlin, 572 p.

BRANDT, A. V.

1970. Fishing off Northwest-Africa. Rapp. P.-V. Reun. Cons. Int. Explor. Mer 159:231-239.

CAUSEY, D.

1953. Parasitic copepoda of Texas coastal fishes. Univ. Tex., Publ. Inst. Mar. Sci. 3:5-16.

CIECHOMSKI, J. D., and G. WEISS.

1973. Desove y desarollo embrionario y larval de besugo, Pagrus pagrus (Linne) en el Mar Agentina (Pisces, Sparidae). Physis, Secc. A, Oceanos Org. 32:481-487.

CORDINI, J. M.

1962. La pesca en el Mar Agentino. Secr. Agr. Ganad. de la Nacion. Buenos Aires:1-28.

CZA.JKA, W., and W. BURAWA.

1970. Trawl nets used by Polish trawlers on fishing grounds of the West African Shelf. Rapp. P.-V. Reun. Cons. Int. Explor. Mer 159:264-271.

DIAS, R. K., J. K. DIAS, and W. D. ANDERSON, JR.

1972. Relationships of lengths (standard, fork, and total) and lengths to weight in the red porgy, Pagrus sedecim (Perciformes,
Sparidae), caught off South Carolina. Trans. Am. Fish. Soc. 101:503-506.

D'ANCONA, U.

1950. Détermination et différenciation du sexe chez les poissons. Arch. Anat. Microsc. Morphol. Exp. 39:274-294.

1956. Inversion spontanées et expérimentales dans les gonades des téléostéens. Annee Biol. 32:89-99.

FOWLER, H. W.

1936. The marine fishes of West Africa based on the collection of the American Museum Congo Expedition, 1909-1915. Bull. Am. Mus. Nat. Hist. 70:607-1493.

GINSBURG, I.

1952. Eight new fishes from the Gulf coast of the United States, with two new genera and notes on geographic distribution. J. Wash. Acad. Sci. 42:84-101.

HILGENDORF, F.

1888. Die Fische der Azoren. Arch. Naturgesch. 54(1):205-213.

HUNTSMAN, G. R.

1976. Offshore headboat fishing in North Carolina and South Carolina. Mar. Fish. Rev. 38(3):13-23.

HUNTSMAN, G. R., and I. MACINTYRE.

1971. Tropical coral patches in Onslow Bay. Underwater Nat. $7(2): 32-34$.

JONES, P. G. W., and A. R. FOLKARD.

1970. Chemical oceanographic observations off the coast of northwest Africa, with special reference to the process of upwelling. Rapp. P.-V. Reun. Cons. Int. Explor. Mer 159:38-60.

JORDAN, D. S., and J. A. GUNN, JR.

1899. List of fishes collected at the Canary Islands by Mr. O. F. Cook, with descriptions of four new species. Proc. Acad. Nat. Sci. Phila. 50:339-347.

KLIMAJ, A

1970. Fishing yield and species composition of trawl catches of M. T. "Ramada" on the fishing grounds on the shelf off Mauritania and Senegal in 1967. Rapp. P.-V. Reun. Cons. Int. Explor. Mer 159:254-260.

LINNAEUS, C.

1758. Systema Naturae, 10th ed. Holmiae. Nantes and Pisces, p. 230-338. (Reprint, 1956, Lond.)

MACINTYRE, I. G., and J. D. MILLIMAN.

1970. Physiographic features on the outer shelf and upper slope, Atlantic Continental Margin, Southeastern United States. Geol. Soc. Am. Bull. 81:2577-2598.

MANOOCH, C. S. III.

1975. A study of the taxonomy, exploitation, life history, ecology and tagging of the red porgy, Pagrus pagrus Linnaeus off the Carolinas. Ph.D. Thesis, North Carolina State Univ., Raleigh, $275 \mathrm{p}$.

1976. Reproductive cycle, fecundity, and sex ratios of the red porgy, Pagrus pagrus (Pisces: Sparidae) in North Carolina. Fish. Bull., U.S. 74:775-781.

In press. Food habits of the red porgy, Pagrus pagrus Linnaeus (Pisces: Sparidae) off North Carolina and South Carolina U.S.A. Bull. Mar. Sci.

MANOOCH, C. S. III, and G. HUNTSMAN.

1977. Age, growth and mortality of the red porgy, Pagrus pagrus. Trans. Am. Fish. Soc. 106:26-33.

MANOOCH, C. S. III, G. R. HUNTSMAN, B. SULLIVAN, and J. ELLIOTT.

1976. Conspecific status of the sparid fishes Pagrus sedecim Ginsburg and Pagrus pagrus Linnaeus. Copeia 1976:678-684.

MONTEIRO, R., and M. L. DIAS.

1970. Sur la peche Portugaise au chalut dans la zone XI (Cote Mauritanienne) du C.I.E.M. (1955-1964). Rapp. P.-V. Reun. Cons. Int. Explor. Mer 159:240-247.

MURRAY, J., and J. HJORT.

1912. The depths of the ocean. Macmillan and Co., Lond., $821 \mathrm{p}$.

RANDALL, J. E.

1968. Caribbean reef fishes. T.F.H. Publ. Inc., Jersey City, N.J., $318 \mathrm{p}$.

RANZI, S.

1969. Family 3: Sparidae. In S. Lo Bianco, Eggs, larvae, and juvenile stages of Teleostei, Parts I and II, p. 330-375. Fauna and 
flora of the Bay of Naples, Monogr. 38. (Translated from Ital., TT68-50346.)

RICKER, W. E.

1975. Computation and interpretation of biological statistics of fish populations. Fish. Res. Board Can. Bull. 191, 382 p.

ROSA, H., JR.

1965. Preparation of synopsis on the biology of species of living aquatic organisms. FAO Fish. Synop. 1, rev. 1, 75 p.

SAVRASOV, V. K.

1970. Fishing vessels, gear and methods at the coast of Africa. Rapp. P. V. Reun. Cons. Int. Explor. Mer 159:248-253.

SEKAVEC, G. B., and G. R. HUNTSMAN.

1972. Reef fishing on the Carolina Continental Shelf. Proc. 15th Annu. Int. Game Fish Res. Conf., p. 76-86.

SOLJAN, T.

1963. Fishes of the Adriatic (Ribe Jarrana). Fauna et Flora Adriatica, Vol. 1, Pisces. (Transl. from Serbo-Croatian, OTS, 60 . 21161, 428 p.)

SPROSTON, N. G.

1946. A synopsis of the monogetic trematodes. Trans. Zool. Soc. Lond. 25:185-600.

\section{STRUHSAKER, P.}

1969. Demersal fish resources: composition, distribution, and commercial potential of the Continental Shelf stocks off Southeastern United States. U.S. Fish Wildl. Serv., Fish. Ind. Res. 4:261-300.
TRAVASSOS, $\mathrm{H}$.

1973. Pagros das aquas Brasileiras. B. Merc. Pesq., Rio de Janerio, GB, 5:321-360.

VALENCIENNES, A

1837-1844. Ichthyologie des iles Canaries, ou historie naturelle des poissons rapportés par $\mathrm{M}$. M. Webb et Berthelot. In $\mathrm{P}$. B. Webb et S. Berthelot, Historie naturelle des iles Canaries, Vol. 2, 109 p., Paris.

WALFORD, L. A.

1946. A new graphic method of describing the growth of animals. Biol. Bull. (Woods Hole) 90:141-147.

WHEELER, A

1969. The fishes of the British Isles and north-west Europe. MacMillan and Co., Ltd., Lond., 613 p.

WOZNIAK, S.

1967. Rozmieszczenie ryb prozmowatych (Sparidae) na szelfie Afryki ponocno - zachodniej (w okresie maj-sierpien 1963 r). Prace Morsk. [Inst. Ryb.] 14(A):7-26.

YESAKI, M., and B. N. BARCELLOS.

1974. Desenvolvimento da pesca do pargo - roseo ao largo da costa sul do Brasil. Programa de pesquisa e desenvolvimento pesqueiro do Brasil. PNUD/FAO. Ministerio da Agricultura/SUDEPE. Serie documentos ocasionais, no. $6,18 \mathrm{p}$.

ZEI, M., and M. ANSA-EMMIM.

1970. The catch of Ghanaian long range trawlers on the shelf off Mauritania and Senegal in 1965/67. Rapp. P.-V. Reun. Cons. Int. Explor. Mer 159:261-263. 



\section{FISHERIES SYNOPSES}

This serles of documents, Issued by FAO, CSIRO, INP, and NMFS, contains comprehensive revlews of present knowledge on specles and stocks of aquatic organlsms of present or potentlal economlc Interest. The Flshery Resources aand Envlronment Division of FAO is responsible for the overall coordination of the serles. The primary purpose of thls serles is to make existing Information readlly avallable to flshery scientlsts according to a standard pattern, and by so doing also to draw attention to gaps In knowledge. It Is hoped that synopses in this series will be useful to other sclentists Inltlating Investlgations of the specles concerned or of related ones, as a means of exchange of knowledge among those already workIng on the specles, and as the basis for comparatlve study of fisheries resources. They will be brought up to date from time to time as further Information becomes available.

The documents of this Serles are Issued under the following titles:

\begin{tabular}{lll} 
FAO & Fisheries Synopals No. & Symbol \\
CSIRO & Fishories Synopsis No. & FIR/S \\
INP & Sinopsis sobrela Pesca No. & DFO/S \\
NMFS & Fisheries Synopsis No. & INP/S \\
\hline
\end{tabular}

Synopses In these serles are complled according to a standard outline described in FIb/S1 Rev. 1 (1965). FAO, CSIRO, INP, and NMFS are workIng to secure the cooperation of other organlzations and of Indivldual sclentlsts In drafting synopses on specles about which they have knowledge, and welcome offers of help In thls task. Additlons and correctlons to synopses aiready Issued will also be most welcome. Comments on Indivldual synopses and requests for informatlon should be addressed to the coordinators and editors of the Issulng organizations, and suggestlons regarding the expanslon or modiflcation of the outline, to FAO:

\section{FAO:}

Fishery Resources and Environment Divislon Aquatic Resources Survey and Evaluation Service Food and Agriculture Organization of the Unlted Nations Vla delle Terme dl Caracalle 00100 Rome, Itaiy

INP:

Instituto Nacional de Pesca

Subsecretarla de Pesca

Secretaria de Pesca

Secretaria de Industrla y Comerclo

Carmona y Valle 101-403

Mexico 7. D.F.

\section{CSIRO:}

CSIRO DIVIslon of Fisherles and Oceanography Box 21

Cronulla, N.S.W. 2230

Australla

\section{NMFS:}

Sclentific Edltor

National Marine Fisherles Service, NOAA

Auke Bay Fisherles Laboratory

P.O. Box 155

Auke Bay, AK 99821

U.S.A.

Consolidated Ilsts of specles or groups covered by synopses Issued to date or In preparation will be Issued from tIme to time. Requests for copies of synopses should be addressed to the issulng organlzation.

The following synopses In this serles have been issued since January 1975:

FIRS/S111

FIRS/S 112

INP/S2

FIR/S115

FIR/S114

FIR/S113
Synopsis of biological data on rohu, Labeo rohita

Synopsls of blologicai data on the Norway lobster, Nephrops norvegicus

Sinopsis de datos biológicos sobre la tortuga golfina, Lepidochelys olivacea

Synopsls of blological data on the largemouth bass, Micropterus sa/moides

Synopsls of blological data on scallops, Chlamys (Aequlpecten) opercularis, Argopecten irradians and Argopecten gibbus

Synopsls of blological data on the perch, Perca fluvlatilis and flavescens
June 1975

September 1975

February 1976

November 1976

December 1976

December 1977 
UNITED STATES

OFFICIAL BUSINESS

\section{NOAA SCIENTIFIC AND TECHNICAL PUBLICATIONS}

NOAA, the National Oceanic and Atmospheric Administration, was established as part of the Department of Commerce on October 3, 1970. The mission responsibilities of NOAA are to monitor and predict the state of the solid Earth, the oceans and their living resources, the atmosphere, and the space environment of the Earth, and to assess the socioeconomic impact of natural and technological changes in the environment.

The six Major Line Components of NOAA regularly produce various types of scientific and technical information in the following kinds of publications:

PROFESSIONAL PAPERS-Important definitive research results, major techniques, and special investigations.

TECHNICAL REPORTS-Journal quality with extensive details, mathematical developments, or data listings.

TECHNICAL MEMORANDUMS-Reports of preliminary, partial, or negative research or technology results, interim instructions, and the like.

CONTRACT AND GRANT REPORTS-Reports prepared by contractors or grantees under NOAA sponsorship.
TECHNICAL SERVICE PUBLICATIONSThese are publications containing data, observations, instructions, etc. A partial listing: Data serials: Prediction and outlook periodicals: Technical manuals. training papers, planning reports, and information serials: and Miscellaneous technical publications.

ATLAS-Analysed data generally presented in the form of maps showing distribution of rainfall, chemical and physical conditions of oceans and atmosphere, distribution of fishes and marine mam. mals, ionospheric conditions, etc.

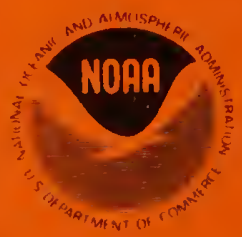

Information on avallablilty of NOAA publications can be obtained from:

ENVIRONMENTAL SCIENCE INFORMATION CENTER ENVIRONMENTAL DATA SERVICE NATIONAL OCEANIC AND ATMOSPHERIC ADMINISTRATION U.S. DEPARTMENT OF COMMERCE 